University of Montana

ScholarWorks at University of Montana

2009

\title{
Arbitration, Bankruptcy and Public Policy: A Contractarian Analysis
}

Paul F. Kirgis

Alexander Blewett III School of Law at the University of Montana, paul.kirgis@umontana.edu

Follow this and additional works at: https://scholarworks.umt.edu/faculty_lawreviews

Part of the Bankruptcy Law Commons, and the Dispute Resolution and Arbitration Commons Let us know how access to this document benefits you.

\section{Recommended Citation}

Kirgis, Paul F., "Arbitration, Bankruptcy and Public Policy: A Contractarian Analysis" (2009). Faculty Law Review Articles. 125.

https://scholarworks.umt.edu/faculty_lawreviews/125

This Article is brought to you for free and open access by the Faculty Publications at ScholarWorks at University of Montana. It has been accepted for inclusion in Faculty Law Review Articles by an authorized administrator of ScholarWorks at University of Montana. For more information, please contact scholarworks@mso.umt.edu. 


\title{
ARBITRATION, BANKRUPTCY, AND PUBLIC POLICY: A CONTRACTARIAN ANALYSIS
}

\author{
CPAUL F. KIRGIS*
}

\begin{abstract}
As arbitration agreements become more common, bankruptcy courts increasingly encounter arbitration agreements to which a bankruptcy debtor is a party. Bankruptcy judges must then determine whether to enforce an otherwise valid arbitration clause or to refuse enforcement and decide the underlying dispute themselves. To date, bankruptcy judges facing these issues have tended to see arbitration as a competing, quasi-judicial forum. They typically refuse to enforce arbitration agreements when they find that bankruptcy policy would favor resolution in the bankruptcy proceeding instead of in some other adjudicative forum. Building on previous work, I contend in this article that arbitration is best understood not as a type of quasi-adjudication, but as a species of contract, with the award equivalent to a contract term agreed upon by the parties ex ante. I argue that arbitration agreements should be enforced by bankruptcy courts unless enforcement would prevent a party from vindicating its statutory bankruptcy rights, and that bankruptcy courts should then decide whether to enforce the award by considering whether the award would contravene the policy of bankruptcy law if it had been a contract term. In practice, my proposal is for enforcement of arbitration agreements with a more robust degree of judicial review of awards than arbitration law typically allows.
\end{abstract}

\section{INTRODUCTION}

Arbitration is an increasingly important—and controversial-part of the legal landscape. The Supreme Court has, in a series of cases since the 1980s, endorsed the use of binding contractual arbitration to resolve disputes of all types, including claims based on federal statutory rights. At the same time, a stable and potent body of bankruptcy law has emerged since the late 1970s, giving bankruptcy judges broad power to decide a range of issues arising in the course of a bankruptcy proceeding. Inevitably, bankruptcy courts increasingly encounter arbitration agreements to which a bankruptcy debtor is a party. A perceived clash between the policy supporting arbitration and the policy favoring centralized resolution of bankruptcy matters often results, leaving bankruptcy judges to determine whether to enforce an otherwise valid arbitration clause or to refuse enforcement and decide the underlying dispute themselves.

"Professor of Law and Associate Dean for Faculty Scholarship, St. John's University School of Law; Faculty Chair, Hugh L. Carey Center for Dispute Resolution. 
To date, bankruptcy judges facing these issues have tended to see arbitration as a competing, quasi-judicial forum. They typically refuse to enforce arbitration agreements when they find that bankruptcy policy would favor resolution in the bankruptcy proceeding instead of in some other adjudicative forum. But the law in this area is highly uncertain. While most courts apply some version of the "competing-policies" approach, few clear standards have emerged to guide courts in determining when to enforce arbitration agreements.

Building on previous work, ${ }^{1}$ I contend in this article that arbitration is best understood not as a type of quasi-adjudication, but as a species of contract, with the award equivalent to a contract term agreed upon ex ante. I argue that arbitration agreements should be enforced by bankruptcy courts unless enforcement would prevent a party from vindicating its statutory bankruptcy rights, and that bankruptcy courts should then decide whether to enforce the award by considering whether the award would contravene the policy of bankruptcy law if it had been a contract term. ${ }^{2}$ In practice, my proposal is for enforcement of arbitration agreements with a more robust degree of judicial review of awards than arbitration law typically allows. Consistent with decades of Supreme Court precedent supporting binding contractual arbitration, this approach would give greater effect to the parties' arbitration agreements. At the same time, it would allow bankruptcy judges to monitor the arbitration process to ensure that the bankruptcy system is not compromised.

I will begin by providing the context in which questions about the enforcement of arbitration agreements in bankruptcy typically arise, providing brief background into both bankruptcy and arbitration law. Then I will describe the existing approaches courts use to decide when to enforce arbitration agreements in bankruptcy. I will critique those approaches, and briefly discuss some of the scholarly suggestions for reform. Then I will explain my approach and how it would change the outcomes of leading cases. I will also note the ways that arbitration providers could make arbitration more palatable for bankruptcy courts.

\footnotetext{
'See Paul F. Kirgis, Judicial Review and the Limits of Arbitral Authority: Lessons from the Law of Contract, 81 ST. JOHN'S L. REV. 99, 103 (2007) [hereinafter Kirgis, Judicial Review] (examining application of same judicial standards to arbitrations of different types of claims); Paul F. Kirgis, The Contractarian Model of Arbitration and Its Implications for Judicial Review of Arbitral Awards, 85 OR. L. REV. 1, 6 (2006) [hereinafter Kirgis, The Contractarian Model] (arguing for greater judicial scrutiny of arbitral awards).

${ }^{2}$ I should make clear at this point that the arbitration agreements I am focusing on tend to be commercial agreements between relatively sophisticated and equal contracting parties. The cases raising these issues fit almost exclusively into that category. See, e.g., In re Knepp, 229 B.R. 821,828 (Bankr. N.D. Ala. 1999) ("When two equally sophisticated parties bargain at arms length to submit disputes to arbitration, that agreement should be enforceable."). I have serious reservations about adhesory arbitration agreements, in consumer and employment contexts especially. My support for enforcement of arbitration agreements in bankruptcy should be understood in that light.
} 


\section{THE LAW OF BANKRUPTCY AND THE LAW OF ARBITRATION}

Bankruptcy and arbitration are both specialized legal disciplines. Where bankruptcy law is rooted in a detailed and complex statutory scheme, however, arbitration law is largely the product of case-law development from a rudimentary statutory starting point. Still, both bodies of law are supported by strong policy underpinnings. Understanding their interrelationship requires understanding the basic legal framework and policy bases of the two fields.

\section{A. Bankruptcy Law \& Policy}

\section{The Effect of Bankruptcy}

Bankruptcy law is designed to serve two primary purposes. First, bankruptcy gives an overburdened debtor a "fresh start." ${ }^{3}$ By relieving debtors of unmanageable obligations, bankruptcy allows debtors to resume or continue productive activity in society. Second, bankruptcy serves the interests of creditors by providing them with an equitable distribution of the debtor's nonexempt assets. ${ }^{4}$ Bankruptcy creates a process in which creditors as a group can receive the highest possible return, while ensuring that no creditor benefits unfairly at the expense of others. ${ }^{5}$

Bankruptcy law uses several mechanisms to accomplish these objectives. Among the most important is the automatic stay. Upon the filing of a bankruptcy petition, an automatic stay goes into effect that serves as an injunction against all collection efforts against the debtor or the debtor's property, wherever located. ${ }^{6}$ The automatic stay forecloses any attempt to collect on a pre-petition debt, the pursuit of any lawsuit to collect a debt, the repossession of the debtor's assets, as well as virtually any other action that would allow a creditor to improve its position with respect to other creditors. ${ }^{7}$ All of the debtor's property then becomes part of the bankruptcy estate, to be used to satisfy the creditors. ${ }^{8}$

Once the automatic stay is in effect, creditors may seek to recover only within the bankruptcy process. ${ }^{9}$ They do this by filing a proof of claim with the bankruptcy

\footnotetext{
${ }^{3}$ See 2 Collier ON BANkruptCY, I 105.01[2], at 105-8 (Alan N. Resnick et al. eds., 15th ed. rev. 2009) (stating affording "fresh start to debtors" is part of bankruptcy courts' mandate).

${ }^{4}$ See id. (describing equitable distribution of funds to creditors as part of bankruptcy courts' mandate).

${ }^{5}$ See $i d$. at 105-74-105-75 ("Unless the claimant engages in some type of inequitable conduct, which results in injury to the debtor's creditors or an unfair advantage to the claimant, the court cannot subordinate a claim to claims within the same class.").

${ }^{6}$ See 11 U.S.C. $\$ 362$ (2006) (explaining details and effects of automatic stay).

${ }^{7}$ See 11 U.S.C. $\$ 362$ (a) (listing collection actions barred under automatic stay).

${ }^{8}$ See 11 U.S.C. $\$ 541$ (a) (2006) (detailing debtor property included in bankruptcy estate). Certain items of the debtor's property will not be available to creditors, either because they are exempt from collection or because they are collateral for a secured creditor. See 11 U.S.C. $\S 362$ (b) (describing debtor property not covered by automatic stay).

${ }^{9}$ See id. Under section 362 , there are some exceptions to the automatic stay, such as the right of a parent to recover for patemity. In addition, the stay can sometimes be lifted in favor of a secured creditor upon a showing that the collateral is at risk or is unnecessary for an effective reorganization. See 11 U.S.C. $\S$
} 
court. ${ }^{10}$ Creditors filing proofs of claim are then sorted into different classes, depending on their interests and the nature of the debts. ${ }^{11}$ Secured creditors are in the best position, because they are entitled to value of their collateral. Unsecured creditors are placed in a priority structure in which certain types of claims are given a preference over others. Priority claims, such as marital support obligations, taxes, and employee wage claims, are paid in full before lower categories of claims are paid at all. ${ }^{12}$ General unsecured creditors are paid last, receiving a pro rata share of whatever is left after claims with higher priority are paid. ${ }^{13}$

There are two main approaches to the satisfaction of creditors' claims in bankruptcy. The first is the liquidation, in which the debtor's nonexempt assets are simply sold and the proceeds used to pay the debts. ${ }^{14}$ This is the chapter 7 bankruptcy, and it is available to natural persons as well as other legal entities. ${ }^{15}$ In the second type of bankruptcy, the debtor retains its assets and continues to function, paying off the debts over time to the greatest extent feasible. ${ }^{16}$ This is the chapter 11 bankruptcy, normally used for business entities, and the chapter 13 bankruptcy, used for individuals with regular income. ${ }^{17}$

The key to the entire bankruptcy process is the estate. The estate exists for the benefit of the creditors. ${ }^{18}$ The estate can include almost any type of asset, and these assets must be managed so that they produce the greatest possible return to the creditors. ${ }^{19}$ Some person must manage the estate so as to maximize its value to creditors. That person can be either a Trustee appointed by the court, or the debtor, who remains in possession of the property in the role of Debtor-in-Possession ("DIP"). ${ }^{20}$ Chapter 7 cases invariably involve a Trustee, while chapter 11 and 13

362(d)(1) (stating court can grant relief from automatic stay if creditor proves lack of adequate protection of interest in such property).

${ }^{10}$ See 11 U.S.C. $\S 362$ (d) ("On request of a party in interest and after notice and a hearing ....").

${ }^{11}$ See 11 U.S.C. $\S 1123(a)(1)$ (2006) (explaining bankruptcy plan should include designation of creditors into classes).

${ }^{12}$ See 11 U.S.C. $\S 507(a)(1)(A)$ (2006) (allowing unsecured claims for spousal domestic support to have first priority).

${ }_{13}^{13}$ See 11 U.S.C. $\$ 726$ (b) (2006) (explaining unsecured creditor claims are paid last, pro rata).

${ }^{14}$ See Kothe v. R.C. Taylor Trust, 280 U.S. 224, 227 (1930) ("The broad purpose of the Bankruptcy Act is to bring about an equitable distribution of the bankrupt's estate among creditors holding just demands based upon adequate consideration.").

${ }^{15}$ See 11 U.S.C. $\S 109$ (c) (2006) (stating entity can be debtor under Bankruptcy Code so long several perquisites are met)

${ }^{16}$ See 11 U.S.C. \&1123(a)(5)(A) (stating reorganization plan should include debtor's retention "of all or any part of the property of the estate").

See generally 1 NORTON BANKRUPTCY LAW \& PRACTICE 3d, § 3:13, at 3-32-3-46 (2008) (providing general overview of chapter 11); 8 COLLIER ON BANKRUPTCY, I 1300.01, at 1300-10-1300-11 (Alan N. Resnick et al. eds., 15th ed. rev. 2006) (providing general overview of chapter 13).

${ }^{18}$ See, e.g., 4 COLLIER ON BANKRUPTCY, I 503.06[1], at 503-24.2 (Alan N. Resnick et al. eds., 15th ed. rev. 2006) (noting benefit to creditors is principal reason preservation costs are given second priority).

${ }^{19}$ See 5 COLLIER ON BANKRUPTCY, 1541.01 , at 541-8.2 (Alan N. Resnick et al. eds., 15th ed. rev. 2006) (emphasizing maximum inclusion of amount of property serves creditors' interests).

${ }^{20}$ See also 1 NORTON BANKRUPTCY LAW \& PRACTICE, supra note 17, at 3-35 (recognizing situations in chapter 11 where trustee is appointed to manage property of estate). 
cases normally involve a DIP. ${ }^{21}$ The basic roles and responsibilities are the same for Trustees and DIPs--they must act to maximize the value of the estate for the creditors. $^{22}$

To accomplish that objective, Trustees and DIPs have certain important powers. Among the most important is the power to pursue claims against third-parties on behalf of both the debtor and the creditors. ${ }^{23}$ Trustees and DIPs may pursue any claim that the debtor would have had in the absence of the bankruptcy, including personal injury actions, breach of contract actions, and claims under federal and state laws regulating everything from fraud to antitrust to discrimination. ${ }^{24}$ Those claims continue to exist independent of the Bankruptcy Code. The Code itself also confers power on Trustees and DIPs to pursue claims designed to protect the corpus of the bankruptcy estate..$^{25}$ This power is called the "avoiding power," and comes in several different varieties. The two most important for purposes of this article are the power to avoid preferential transfers and the power to avoid fraudulent conveyances. ${ }^{26}$

Preferential transfers are transfers of money or other assets to a particular creditor prior to the bankruptcy filing. In the absence of bankruptcy, a debtor has the option of paying one creditor more than another. But once bankruptcy is on the horizon, it would defeat one of the key objectives of bankruptcy-treating all creditors equally - to allow debtors that kind of flexibility. Bankruptcy law deals with that problem by effectively preventing the payment of any debts by an insolvent debtor in the lead-up to the bankruptcy filing. It does this by allowing a Trustee or DIP to avoid any transfer of the property of an insolvent debtor in payment of an antecedent debt if made within 90 days of the bankruptcy filing. ${ }^{27}$

Outside of bankruptcy, creditors are protected by laws barring debtors from transferring property for less than it is worth, if the transfer will leave the debtor insolvent or is made with an actual intent to escape payment to the creditor ${ }^{28}$ Every state has a law, many patterned after the Uniform Fraudulent Conveyances Act,

${ }^{21}$ See 11 U.S.C. $\$ 1107$ (2006) ("[A] debtor in possession shall have all the rights . . . and powers, and shall perform all the functions and duties . . . of a trustee serving in a case under [chapter 11]."); 1 NORTON BANKRUPTCY LAW \& PRACTICE, supra note 17, at 3-30 (stating every chapter 7 case will involve either U.S. Trustee or private trustee).

${ }^{22}$ See 11 U.S.C. $\$ 1107$ (granting to debtor-in-possession all rights and powers of trustee).

${ }^{23}$ See 4 Norton BANKRUPTCY LAW \& PRACTICE 3d, \& 61:7, at 61-35 n.12 (2009) (collecting cases holding that causes of action belonging to either debtors or creditors are property of estate).

${ }^{24}$ See id. at 61-34 (enumerating various causes of action that become property of estate).

${ }^{25}$ See John C. Chobot, Preserving Liens Avoided in Bankruptcy - Limitations and Applications, 62 AM. BANKR. L.J. 149, 149 (1988) (describing how Bankruptcy Code confers upon trustee or debtor in possession avoidance powers for certain pre-petition transfers, preserving them for estate's benefit).

${ }^{26}$ See generally John D. Ayer et al., Overview of Avoidance Actions, 23 AM. BANKR. INST. J. 26, 27-56 (Mar. 2004) (discussing power of trustee or debtor in possession to avoid pre-petition fraudulent or preferential transfers).

${ }^{27}$ See 11 U.S.C. $\$ 547$ (b) (2006) (describing elements of preferential transfers).

${ }^{28}$ See Marie T. Reilly, A Search for Reason in "Reasonably Equivalent Value" After BFP v. Resolution Trust Corp., 13 AM. BANKR. INST. L. REV. 261, 261 (2005) (acknowledging how state fraudulent transfer law enables creditor to avoid transfers of property made by debtor if transfer intended to "hinder, delay, or defraud" creditor or if creditor can prove debtor engaged in constructive fraud). 
allowing creditors harmed in this way to bring suit to avoid the fraudulent transfer. ${ }^{29}$ Once the debtor enters bankruptcy, the Trustee or DIP stands in the shoes of the creditors for purposes of avoiding fraudulent transfers. ${ }^{30}$ Under section 544 of the Bankruptcy Code, the Trustee or DIP may bring suit to enforce the creditors' rights to avoid fraudulent transfers. ${ }^{31}$ These are simply state law claims that the trustee may enforce on behalf of creditors because of the operation of the bankruptcy laws. ${ }^{32}$

\section{Assumption or Rejection of Executory Contracts}

One of the most important powers that Trustees and DIPs have is the power to assume or reject executory contracts. An executory contract is a contract "under which the obligation of both the bankrupt and the other party to the contract are so far unperformed that the failure of either to complete performance would constitute a material breach excusing the performance of the other. ${ }^{133}$ In other words, executory contracts are contracts in which neither party has completed performance. ${ }^{34}$

${ }^{29}$ See Elaine A. Welle, Is It Time for Wyoming to Update its Fraudulent Conveyance Laws?, 5 WYO. L. REV. 207, 214-15 (2005) (discussing how twenty-six states had adopted Uniform Fraudulent Conveyance Act, however as of 2005 , forty-two states, including twenty-three of those which had adopted U.F.C.A., have adopted Uniform Fraudulent Transfer Act, promulgated by National Conference of Commissioners on Uniform State Laws to replace U.F.C.A. due to inconsistencies between U.F.C.A. and federal bankruptcy law).

${ }^{30}$ See David R. Weinstein \& Gil Hopenstand, Reachbacks, Statutes of Limitation and Deadlines, 26 AM. BANKR. INST. J. 1, 1 (June 2007) ("For decades, a bankruptcy trustee has been entitled to 'step into the shoes' of an actual creditor of the debtor so as to avoid transfers by the debtor, typically fraudulent transfers.").

${ }^{31}$ See 11 U.S.C. \$ 548(a)(1) (2006) (providing trustee may avoid any voluntary or involuntary transfer of interest of debtor in property made on or within two years of date of filing of bankruptcy petition if transfer was made with actual intent to defraud, or was made in exchange for "less than a reasonably equivalent value" and any of series of additional conditions are satisfied).

${ }^{32}$ See Weinstein \& Hopenstand, supra note 30, at 64 (observing how Bankruptcy Code "enables trustee to 'step into the shoes' of an actual creditor of the estate who had rights, still alive as of the petition date, to sue to avoid transfers by the debtor under nonbankruptcy law").

${ }^{33}$ See Vern Countryman, Executory Contracts in Bankruptcy, Part 1, 57 MrNN. L. REv. 439, 460 (1973). This test became the most widely-accepted definition of executory contracts in the courts. See, e.g., Kimmelman v. Port Auth. (In re Kiwi Int'l Air Lines, Inc.), 344 F.3d 311, 317-18 n.5 (3d Cir. 2003) (applying Professor Countryman's definition of executory contract); Unsecured Creditors' Comm. of Robert L. Helms Constr. \& Dev. Co. v. Southmark Corp. (In re Robert L. Helms Constr. \& Dev. Co.), 139 F.3d 702, 705 (9th Cir. 1998) (endorsing Professor Countryman's definition of executory contract); Kaler v. Craig (In re Craig), 144 F.3d 593, 596 (8th Cir. 1998) (using Professor Countryman's definition of executory contract); see also Jay L. Westbrook, A Functional Analysis of Executory Contracts, 74 MINN. L. REV. 227, 236-37 (1989) (noting Professor Countryman's definition for executory contracts is standard).

${ }^{34}$ See Countryman, supra note 33 , at 460 (describing an executor contract as "a contract under which the obligation of both the bankrupt and the other party to the contract are so far underperformed that the failure of either to complete performance would constitute a material breach . . . ."). Needless to say to anyone familiar with first-year contracts, the law is extremely vague as to when performance is complete, with centuries of case law on the twin questions of substantial performance and material breach. See Celia R. Taylor, Self-Help In Contract Law: An Exploration And Proposal, 33 WAKE ForeST L. REV. 839, 861 (1998) (explaining doctrines of substantial performance and material breach are difficult to define and plague many areas of contract law). 
To understand how executory contracts are treated, first consider the situation in which a contract has been fully performed by one party. Assume the bankruptcy debtor has a contract to supply widgets to a purchaser. The debtor has provided all the widgets called for under the contract, but has not been paid. The claim for payment due against the counterparty purchaser is simply a claim of the estate that the Trustee or DIP may pursue. If the situation is reversed, and the debtor has been paid for the widgets but has not supplied them, the bankruptcy serves as a breach of the contract and entitles the counterparty to pursue damages as a claim against the estate. That claim will likely be paid out in pennies on the dollar.

For executory contracts, the Trustee or DIP has a choice of how to proceed: assumption or rejection. If an executory contract is assumed, then the Trustee or DIP performs the contract, making any necessary payments out of the estate as administrative expenses. If it is rejected, then the other party to the contract is entitled to damages, to be paid out of the estate upon distribution on the same basis as any other unsecured claim. Effectively, if the Trustee or DIP concludes that the estate will benefit from performance of a contract, the Trustee or DIP assumes it. If the Trustee or DIP concludes that performance would create a drain on the estate, the contract is rejected. ${ }^{35}$

Trustees and DIPs also have many other powers. But these, coupled with the bankruptcy court jurisdiction analysis in the next section, are the key ingredients to understanding the enforcement of arbitration clauses in bankruptcy.

\section{Bankruptcy Jurisdiction \& Process}

The Bankruptcy Reform Act of 1978 gave bankruptcy courts the same powers as district courts with respect to most claims involving a bankruptcy debtor. ${ }^{36}$ Once the Debtor filed for bankruptcy, virtually any action on behalf of or against the debtor could be heard and decided by a bankruptcy judge. Bankruptcy courts decided any matter that directly involved the operation of the bankruptcy laws, and also decided the whole range of cases involving bankruptcy debtors and rooted in state or federal laws outside bankruptcy. In 1982, in Nothern Pipeline Constr. Co. v. Marathon Pipe Line Co., the Supreme Court held the 1978 Act unconstitutional because that broad jurisdictional grant gave non-Article III bankruptcy judges power to decide many claims not created by bankruptcy law. ${ }^{37}$ The Court concluded, in a plurality opinion, that bankruptcy judges could decide matters

\footnotetext{
${ }^{35}$ See Westbrook, supra note 33, at 288 (demonstrating example of DIP rejecting contract because performance will not help estate). Westbrook argues that the distinction between executory and nonexecutory contracts is artificial, and that all contracts are subject to the same analysis: if it would benefit the estate to proceed with any outstanding contractual obligations, the contract is assumed; if it would benefit the estate more to breach, the contract is rejected and damages paid out of the estate. See id. at 335.

3628 U.S.C. \& 1471(a) (1978) ("[T]he district courts shall have original and exclusive jurisdiction of all cases under title $11 . ")$.

${ }^{37}$ N. Pipeline Const. Co. v. Marathon Pipe Line Co., 458 U.S. 50, 76 (1982) (holding Bankruptcy Reform Act's broad jurisdiction power arising or related under title 11 violates Article III of Constitution).
} 
involving "the restructuring of debtor-creditor relations, which is at the core of the federal bankruptcy power," but could not adjudicate "state-created private rights, such as the right to recover contract damages. ${ }^{138}$

To cure the constitutional problem, Congress amended the Bankruptcy Code to create different classes of matters that bankruptcy courts may hear, with different decisional powers associated with them. District courts still have very broad bankruptcy jurisdiction - they can decide matters that "arise under" the Bankruptcy Code, "arise in" a case under the Bankruptcy Code, or are "related to" a bankruptcy case. ${ }^{39}$ The latter category has been defined to encompass any matter that "could conceivably have any effect on the estate being administered in bankruptcy." ${ }^{40}$ The district courts may refer any of these matters to a bankruptcy court, but the bankruptcy court may enter an order or judgment only for matters "arising under" the Code or "arising in" a case under the Code. For matters "relating to" a bankruptcy case, the bankruptcy court may make only proposed findings of fact and conclusions of law, to be submitted to the district court for it to enter orders or judgments.

This jurisdictional structure creates a distinction between "core" and "noncore" proceedings. Core proceedings include matters arising under the Code or arising in a case under the Code. ${ }^{41}$ Section 157(b)(2) of the Bankruptcy Code gives a nonexclusive list of the matters considered core proceedings, including objections to a creditor's proof of claim, preference actions, counterclaims against persons filing claims against the estate, and challenges to the automatic stay or to the discharge of debts. ${ }^{42}$ Matters that do not raise bankruptcy issues, such as breach of contract or fraud actions brought on behalf of the debtor by a Trustee against a third-party, are considered noncore proceedings. ${ }^{43}$

Bankruptcy courts almost always hear and decide core proceedings in the first instance. They also hear many noncore proceedings, but again, the bankruptcy court may not issue binding orders and judgments unless the parties consent. In the absence of consent, the bankruptcy court's determinations are merely advisory for the district court. As a result of this bifurcation, it is not unusual for district courts to hear noncore claims involving a bankrupt debtor.

Because of this jurisdictional structure, both district courts and bankruptcy courts face questions about the enforceability of arbitration clauses and awards in bankruptcy. They must apply the federal law of arbitration, which I describe next.

\footnotetext{
${ }^{38}$ Id. at 71 .

${ }^{39}$ See 28 U.S.C. $\S 1334$ (b) (2000) ("[D]istrict courts shall have original but not exclusive jurisdiction of all civil proceedings arising under title 11 , or arising in or related to cases under title $11 . ")$.

${ }^{40}$ Pacor, Inc. v. Higgins (In re Pacor, Inc.), 743 F.2d 984, 994 (3d Cir. 1984).

${ }^{41}$ See 28 U.S.C. $\S 157($ b)(1) (2000) (granting bankruptcy court jurisdiction over "all core proceedings arising under title 11 , or arising in a case under title $11 ")$.

428 U.S.C. $\$ 157(\mathrm{~b})(2)$ (illustrating various core proceedings).

${ }^{43}$ See Alan N. Resnick, The Enforceability of Arbitration Clauses in Bankruptcy, 15 AM. BANKR. INST. L. REV. 183, 194 (2007) (classifying trustee claims against third parties non-core because they "do[] not present any bankruptcy issues").
} 


\section{B. Arbitration Law \& Policy}

Like bankruptcy law, arbitration law has its origins in a federal statute, though one that is much less comprehensive. Also like bankruptcy law, it has undergone significant changes in the last three decades, and it occupies a special place within the procedural structures of the federal court system.

\section{The Federal Law of Arbitration}

The principal source of arbitration law is the Federal Arbitration Act ("FAA"). ${ }^{44}$ Enacted in 1925 with the express goal of abrogating judicial resistance to the enforcement of arbitration agreements, ${ }^{45}$ the FAA has three primary purposes. First, it makes agreements to arbitrate enforceable, backed by the remedy of specific performance. It accomplishes this objective by conferring a right to apply to a federal district court to enforce any arbitration agreement in a contract "evidencing a transaction involving [interstate] commerce." ${ }^{.46} \mathrm{~A}$ party seeking to enforce an arbitration agreement may move to stay litigation if litigation has already been commenced, or may move to compel a reluctant party to proceed with arbitration. ${ }^{47}$ Second, the FAA provides a mechanism for judicial enforcement of arbitral awards. ${ }^{48}$ If the parties provide for judicial enforcement in their agreement, then a district court must enter the award as a judgment of the court, thereby making available all the process normally available to satisfy a civil judgment. ${ }^{49}$ Finally, the FAA makes arbitral awards final by severely proscribing the grounds available for judicial review of arbitral awards. ${ }^{50}$

Most states also have arbitration statutes designed to achieve these goals. ${ }^{51}$ But the Supreme Court has given the FAA an extremely broad reach, holding that it pre-

\footnotetext{
${ }^{44}$ See 9 U.S.C. $\$ 1$ (2000) (controlling over virtually all interstate commerce contracts). When enacted, the FAA was called the United States Arbitration Act. E.g., Claire Kennedy-Wilkins, Playing Ostrich with the FAA's History: The Scope of Mandatory Arbitration of Employment Contracts, 54 HASTINGS L.J. 1593, 1593 n.4 (2003) (noting Act originally codified United States Arbitration Act but now "uniformly" called FAA).

${ }^{45}$ See Allied-Bruce Terminix Cos. v. Dobson, 513 U.S. 265, 270 (1995) ("[T]he basic purpose of the Federal Arbitration Act is to overcome courts' refusals to enforce agreements to arbitrate.").

469 U.S.C. $\$ 2$ (2000) (holding such arbitration clauses "valid, irrevocable, and enforceable.")

${ }^{47}$ See 9 U.S.C. $\S \S 3-4(2000)$ (permitting court ordered arbitration or referral upon request where adverse party under contractual arbitration agreement).

${ }^{48}$ See 9 U.S.C. $\$ 9(2000)$ (authorizing arbitration award execution where award notice served by treating adverse party "as though he had appeared generally" before court).

${ }^{49}$ See id. (noting "the court must grant" an order confirming award made pursuant to arbitration "unless [that] order is vacated, modified, or corrected").

${ }_{50}$ See 9 U.S.C. $\$ 10(2000)$ (determining district court may vacate award if it was "procured by corruption, fraud, or undue means" or where arbitrators were guilty of misconduct, partiality, or corruption).

${ }^{51}$ Many state arbitration statutes are based on the Uniform Arbitration Act, adopted by the National Conference of the Commissioners on Uniform State Laws in 1955. See UNIF. ARB. ACT (2000) ("Forty-nine jurisdictions have arbitration statutes; 35 of these have adopted the UAA and 14 have adopted substantially similar legislation.") available at http://www.nccusl.org/nccusl/uniformact_summaries/uniformacts-s-aa.asp.
} 
empts state laws less favorable to arbitration ${ }^{52}$ and applies to the full extent of Congress's commerce clause power. ${ }^{53}$ It binds both federal and state courts as long as the matter involves interstate or foreign commerce. ${ }^{54}$ Thus, the FAA and, perhaps more importantly given the brevity of the FAA, the case law interpreting it have come to dominate the law of arbitration.

\section{The Federal Policy Favoring Enforcement of Arbitration Agreements}

The FAA was enacted as a limited measure to counteract judicial hostility to arbitration. It was intended mainly to apply to commercial agreements between roughly equal parties. In recent years, however, the FAA has become something very different. Courts, especially the Supreme Court, have used it to push a radically pro-arbitration agenda. As a result, arbitration clauses are now upheld and enforced in an enormous range of contract, including many that end up the source of disputes in bankruptcy.

\section{a. Initial Hesitation in Applying the FAA}

For a number of years after the enactment of the FAA, courts continued to see arbitration as, at best, a second-class alternative to formal adjudication. Consequently, they initially interpreted the FAA narrowly. The Supreme Court's 1953 decision in Wilko v. Swan ${ }^{55}$ is the most prominent example of that mindset. In Wilko, the Supreme Court refused to compel arbitration of an investor's fraud claims against a securities broker under the Securities Act of 1933, which declared void any "condition, stipulation, or provision binding any person acquiring any security to waive compliance with any provision" of the Act. ${ }^{56}$ The Court focused on the inadequacy of arbitration as a substitute for formal adjudication. The Court emphasized that the arbitrators would not have a judge to instruct them on the law and, even conceding their obligation to apply the law, would be under no obligation to produce a reasoned opinion allowing for meaningful judicial review. On that

\footnotetext{
${ }^{52}$ See Southland Corp. v. Keating, 465 U.S. 1,13 (1984) (noting legislature "contemplated a broad reach of the Act, unencumbered by state law constraints").

${ }^{53}$ See Allied-Bruce Terminix Cos. v. Dobson, 513 U.S. 265, 274 (1995) (describing "the Act's reach expansively as coinciding with that of the Commerce Clause").

${ }^{54}$ But see 9 U.S.C. \& $1(2000)$ (defining commerce term as "commerce among the several [s]tates or with foreign nations, or in any [t]erritory of the United States or in the District of Columbia, or between any such [t]erritory and another"). The contracts to which FAA applies does not include "contracts of employment of seamen, railroad employees, or any other class of workers engaged in foreign or interstate commerce." Id. The Supreme Court has interpreted the last clause narrowly, to cover only workers in the transportation industry. See Circuit City Stores, Inc. v. Adams, 532 U.S. 105, 118-19 (2001) (construing 9 U.S.C. \& 1 to exclude nearly all employment contracts from FFA but include employment contracts of transportation employees).

s5 346 U.S. 427 (1953), overruled by Rodriguez de Quijas v. Shearson/Am. Express, Inc., 490 U.S. 477 (1989).

${ }^{56}$ Wilko, 346 U.S. at 430.
} 
basis, the Court held that the Securities Act precluded the enforcement of the arbitration agreement.

Despite its hesitation about the arbitration of statutory claims, during this period, the Court threw its support behind arbitration in cases not involving statutory claims. Arbitration became the primary mechanism for resolving labormanagement disputes. ${ }^{57}$ And Prima Paint Corp. v. Flood \& Conklin Mfg. Co. ${ }^{58}$ confirmed the broad enforceability of arbitration agreements in commercial cases by holding that even the issue of fraud in the inducement of the agreement to arbitrate must be decided by the arbitrator.

\section{b. The Era of Expansion}

Gradually, the Supreme Court's reticence about arbitration faded. In Scherk v. Alberto-Culver Co. ${ }^{59}$ a German citizen sued by an American company for fraud under section 10 of the Securities Exchange Act of 1934 sought to enforce an arbitration agreement. The Supreme Court held the agreement enforceable. The Court distinguished Wilko but did not overrule it. It concluded that the nature of the statutory rights at issue was different because the Securities Exchange Act of 1934 implied a private right of action whereas the Securities Act of 1933 expressly provided a "special right." It also found an important distinction in the fact that the transaction in Scherk involved parties to an international agreement, whereas Wilko involved a private U.S. citizen suing other U.S. citizens. ${ }^{60}$

Although limited, Scherk was a sign of things to come. In the mid-1980s, beginning with Mitsubishi Motors Corp. v. Soler Chrysler-Plymouth Inc. ${ }^{61}$ the Court firmly committed itself to arbitrability in virtually every context. Mitsubishi, like Scherk, involved a dispute arising out of an international commercial agreement. Instead of securities fraud, the claims alleged antitrust violations. ${ }^{62}$ The Supreme Court held the antitrust claims arbitrable, finding that the statutory rights at issue could be "effectively vindicated" in arbitration. ${ }^{63}$ Two years later, in Shearson/American Express Inc. v. McMahon ${ }^{64}$ the Court extended Scherk by enforcing an arbitration clause in a case alleging garden-variety fraud claims against

\footnotetext{
57 See United Steelworkers of Am. v. Warrior \& Gulf Navigation Co., 363 U.S. 574, 581 (1960) (discussing how arbitration offers agreeable solutions to meet needs of all participants in labor-management disputes).

588 U.S. 395 (1967).

59417 U.S. 506 (1974).

${ }^{60} \mathrm{Id}$. at 515-16 (discussing hazards of conflict-of-laws problems occurring in international contracts).

${ }^{61} 473$ U.S. 614 (1985).

${ }^{62}$ Id. at 624-25 (considering enforcement of arbitration clause to settle antitrust claim that arose from international transaction).

${ }^{63}$ Id. at 637 ("[S]o long as the prospective litigant effectively may vindicate its statutory cause of action in the arbitral forum, the statute will continue to serve both its remedial and deterrent function.").

${ }^{64} 482$ U.S. 220 (1987).
} 
a securities broker under the Securities Exchange Act of 1934 and RICO. ${ }^{65}$ Two years after that, in Rodriguez de Quijas v. Shearson/American Express, Inc., ${ }^{66}$ the Court finally put Wilko to rest by holding claims under the Securities Act of 1933 arbitrable. And in 1991, in Gilmer v. Interstate/Johnson Lane Corp., ${ }^{67}$ the Court enforced an arbitration clause in a dispute involving employment discrimination claims under the Age Discrimination in Employment Act of $1967 .^{68}$ In each of these decisions, the Court rejected the "suspicion of arbitration" and emphasized arbitration's effectiveness in vindicating statutory rights.

Since the early 1990s, the Court has remained steadfast in its support for arbitration as an alternative to formal adjudication. It has recognized only one limitation on arbitrability: cost. In Green Tree Fin. Corp.-Alabama v. Randolph, ${ }^{69}$ a home purchaser argued that she should not have to arbitrate her fraud claims against her lender because the cost of arbitration would be so high it would dissuade her and others like her from taking action to enforce statutory rights. The Supreme Court found a lack of evidence in the record to show how expensive arbitration would be, but it acknowledged that a claim of this type might have validity: "It may well be that the existence of large arbitration costs could preclude a litigant such as Randolph from effectively vindicating her federal statutory rights in the arbitral forum. ${ }^{70}$ Lower courts have relied on Green Tree to refuse enforcement of feesplitting provisions in arbitration clauses that would have the effect of imposing costs on arbitration claimants that would exceed the court costs a litigant would be likely to face. ${ }^{71}$

In sum, over the last three decades, the Supreme Court has removed virtually every obstacle to arbitration. Any claim, including statutory claims under the discrimination laws, is potentially arbitrable. And any party, including those with radically unequal bargaining power, can be held to an arbitration agreement, as long as high costs do not preclude a party from vindicating important legal rights.

\section{The Intersection of Arbitration and Bankruptcy}

Virtually any contractual relationship can become the subject of a dispute in bankruptcy, and because almost any contract can include an arbitration clause, the variety of cases in which arbitration and bankruptcy can collide is nearly limitless. But there are three main circumstances in which arbitration arises in bankruptcy that provide good illustrations of the most common conflicts. In the first type of case,

\footnotetext{
${ }^{65} I d$. at 223. The aggrieved investors alleged "fraudulent, excessive trading on respondents' accounts and . . making false statements and omitting material facts from the advice given to respondents." Id.

${ }^{66} 490$ U.S. 477 (1989).

${ }^{67} 500$ U.S. 20 (1991).

6829 U.S.C. $\$ 621(2000)$.

${ }^{69} 531$ U.S. 79 (2000).

${ }^{70} \mathrm{Id}$. at 90 .

${ }^{7}$ See Shankle v. B-G Maint. Mgmt. of Colo., Inc., 163 F.3d 1230, 1235 (10th Cir. 1999) (holding feesplitting clause requiring claimant to pay one-half of arbitration costs "failed to provide an accessible forum in which [claimant] could resolve his statutory rights").
} 
either a Trustee or DIP sues a counterparty to a contract of the debtor's to recover money on a common-law or statutory claim, typically for breach of contract or fraud. That action is often brought in a district court, but could also be brought in a bankruptcy court as a noncore proceeding. The counterparty moves to enforce an arbitration clause.

One of the leading cases addressing arbitration in bankruptcy, Hays \& Co. $v$. Merrill Lynch, Pierce, Fenner \& Smith, Inc., ${ }^{72}$ involved, in part, that situation. In Hays, the Trustee in the debtor's chapter 11 bankruptcy sued Merrill Lynch, with whom the debtor held trading accounts, in district court alleging that Merrill Lynch had engaged in "churning," improperly invested in speculative securities, and breached its fiduciary duty by comingling funds in personal and corporate accounts. ${ }^{73}$ These claims were based on federal and state securities statutes, RICO, and state common law. ${ }^{74}$ Merrill Lynch filed a motion in the district court seeking to enforce the arbitration clause in its customer agreement with the debtor. ${ }^{75}$ The Third Circuit held those claims arbitrable, for reasons I will explain later.

In the second type of case, the Trustee or DIP pursues a preference action against one of the debtor's counterparties to avoid transfers made to the counterparty prior to the bankruptcy filing. Preference actions, which are core, may be maintained either in the district court or in the bankruptcy court, depending on what other claims the Trustee or DIP is asserting. Again, the counterparty usually moves to enforce the arbitration clause, while the Trustee or DIP prefers to have the matter decided by the district court or, even better, the bankruptcy court. Hays involved this type of claim as well. In addition to the statutory and common-law fraud claims, the Trustee in Hays sought to avoid transfers made to Merrill Lynch, relying on section 544(b) of the Bankruptcy Code.$^{76}$ That section allows a Trustee to pursue any claims for the recovery of fraudulent conveyances that a creditor could have pursued under state law in the absence of bankruptcy. ${ }^{77}$ The Hays Trustee pursued claims in the district court under the Uniform Fraudulent

\footnotetext{
${ }^{72} 885$ F.2d 1149 (3d Cir. 1989).

${ }^{73}$ See id. at 1150 (alleging debtor requested money be invested only in "long term good quality" securities while defendant made risky investments without disclosing possible pitfalls to debtor resulting in loss for debtor of approximately $\$ 200,000$, according to Trustee).

${ }_{74}^{7 d}$. (alleging "claims under section 17 (a) of the Securities Act of 1933, 15 U.S.C.A. $\$ 77 q(a)$, and section 10(b) of the Securities and Exchange Act of 1934, 15 U.S.C.A. § 78j(b); common law claims for breach of contract and fiduciary duties, gross negligence, and conversion; claims under the New Jersey Uniform Securities Law, N.J.S.A. $\S 49: 3-47$ to 49:3-76, the Pennsylvania Securities Act of 1972, 70 P.S. $\$ \S 1-101$ to 1-704; several claims under the Racketeer Influenced and Corrupt Organizations Act, 18 U.S.C.A. $\S ~ 1961-$ 1968 ("RICO").").

${ }^{75}$ Id. at $1150-51$.

${ }^{76} \mathrm{Id}$. at 1150 ("[Trustee] filed this action in district court alleging ... equitable claims pursuant to $\S 544(\mathrm{~b})$ $\ldots=$.

${ }^{77}$ See 11 U.S.C. $\$ 544$ (b) (2006) ("Except as provided in paragraph (2), the trustee may avoid any transfer of an interest of the debtor in property or any obligation incurred by the debtor that is voidable under applicable law by a creditor holding an unsecured claim that is allowable under section 502 of this title or that is not allowable only under section 502(e) of this title.").
} 
Conveyances Acts of New York, New Jersey, and Pennsylvania. ${ }^{78}$ Again, Merrill Lynch moved for arbitration. For these claims, however, the Third Circuit held that arbitration was not available. ${ }^{79} \mathrm{I}$ will explain that reasoning more later.

In the third type of case, the Trustee or DIP rejects an executory contract and the counterparty to the contract seeks to enforce an arbitration clause to determine the damages resulting from the rejection. For example, in Societe Nationale Algerienne v. Distrigas Corp. ${ }^{80}$ the DIP in a chapter 11 bankruptcy rejected a twenty-year contract for the purchase and sale of natural gas. The counterparty moved in the bankruptcy court to compel arbitration before the International Chamber of Commerce in Geneva, as provided in the agreement, in order to determine the damages to the counterparty from the rejection of the underlying contract. The DIP objected, preferring the bankruptcy court to a foreign arbitral tribunal. ${ }^{81}$ The bankruptcy court held that the arbitration agreement was enforceable and sent the dispute to the international arbitration panel. ${ }^{82}$

These cases, as well as the more unusual ones that find their way into the reporters, create a dilemma for judges who have been conditioned to enforce arbitration clauses without a second thought, but who are also highly sensitive to the centralizing pull of the bankruptcy process. They tend to see the tension as a choice between competing forums - the arbitration panel or the bankruptcy court (or district court). Viewed this way, the choice of forum represents a conflict between the purposes of arbitration law and the purposes of bankruptcy law. Courts adopting this mindset focus on the policy implications of allowing an arbitrator to make a decision that will have an effect on the recovery available to other creditors. As I'll demonstrate in the next section, they essentially balance the policy in favor of arbitration against the policy in favor of consolidated and expedited bankruptcy resolution.

\footnotetext{
${ }^{78}$ Hays \& Co., 885 F.2d at 1150 (pursuing equitable relief under statutes and constructive trust theories pursuant to 11 U.S.C. $\$ 544(\mathrm{~b}))$.

${ }^{79}$ Id. at 1155 (holding claims asserted by Trustee under section 544(b) are "creditor claims" asserted on creditors' behalf and not on bankrupt party's behalf and so parties to original contract were not directly involved, yielding provision unenforceable).

${ }^{80} 80$ B.R. 606 (D. Mass. 1987).

${ }^{81}$ Id. at $607 \mathrm{n} .2$ ("Measuring the damages by the benefit-of-the-bargain, [the creditor] claims 1.2 billion dollars. While [the debtor] could never satisfy such an enormous award, were one to be made, [the debtor] is the wholly owned subsidiary of [Cabot Cabot \& Forbes] and [the creditor] seems to believe that it may be better able to lift the corporate veil in an international forum than here at home. For its part, [the debtor] prefers to remain veiled before a known Bankruptcy Judge rather than endure the uncertainties of an international tribunal of 'three foreigners."').

${ }^{82}$ Id. at 613 ("Taken together, these decisions erect a compelling argument in favor of requiring [the debtor] - as a 'representative of the American business community,- - to honor its bargain and proceed with international arbitration.").
} 


\section{EXISTING APPROACHES TO THE ENFORCEMENT OF ARBITRATION AGREEMENTS IN BANKRUPTCY}

The Supreme Court has yet to weigh in on the enforceability of arbitration clauses in bankruptcy. As a result, the Circuit Courts have driven the development of the law in this area. While some consistent rules have emerged, a great deal of confusion and disparity exists, with a significant circuit split emerging. Academic commentators have suggested several approaches to clarify the morass, but none have been adopted as of yet.

The real problem with the existing approach is that it rests on a flawed foundation. The case that the courts use as their starting point, Shearson/American Express v. McMahon, ${ }^{83}$ dealt with an entirely different question. It cannot do the lifting that the courts have asked of it in the bankruptcy context. By focusing on it, courts have failed to see that arbitration law already provides doctrines that will allow for the robust enforcement of arbitration clauses while protecting the policies animating the bankruptcy system.

\section{A. The Current Framework for Analyzing the Enforcement of Arbitration Agreements in Bankruptcy}

The current framework provides a relatively clear distinction between treatment of core and noncore proceedings, but bogs down on the question of when an arbitration clause covering a core matter should be enforced. The latter question is where McMahon comes into play, and where courts get off track.

\section{The Core/Noncore Distinction}

The core/noncore distinction provides one relatively bright-line rule on the enforcement of arbitration agreements in bankruptcy. Again, core claims are those that arise under the Bankruptcy Code or arise in a case under the Bankruptcy Code. They are claims that are made possible by the operation of the Bankruptcy Code. Noncore claims exist and could be pursued entirely outside bankruptcy law.

The courts are in wide agreement that both district and bankruptcy courts must enforce an otherwise valid arbitration clause covering a noncore claim. ${ }^{84}$ Noncore claims do not rest on substantive rights created by bankruptcy claw. They are based

\footnotetext{
${ }^{83} 482$ U.S. 220 (1987).

${ }^{84}$ See Marianne B. Culhane \& Michaela M. White, Enforcing (or not) Arbitration Clauses in Bankruptcy, 1362 PRAC. L. INSTI. CORP. L. \& PRAC. HANDBOOK SERIES 39, 48 (2003) ("[T] he presumption is that if the dispute is covered by an otherwise valid arbitration agreement, the agreement should be enforced .... Generally, bankruptcy courts are found to have no discretion to deny motions to stay pending arbitration in debtor-derivative non-core matters . . ."). But see U.S. Lines, Inc. v. Am. Steamship Owners Mut. Prot. and Indem. Assoc. (In re U.S. Lines), 197 F.3d 631, 640 (2d Cir. 1999) (noting conflict between arbitration law and bankruptcy law "is lessened in non-core proceedings which are unlikely to present a conflict sufficient to override by implication the presumption in favor of arbitration").
} 
on state or federal laws outside the Bankruptcy Code. Bankruptcy courts hear them only in their advisory role as adjuncts to the district courts. Bankruptcy judges step into the shoes of district court judges when hearing noncore claims. They must apply state and federal laws in the same way district court judges would. Accordingly, they have no discretion to refuse to compel arbitration if a district court judge could not refuse to compel arbitration when hearing the same claims in a nonbankruptcy context.

The core/noncore distinction was the basis for the first part of the decision in Hays. ${ }^{85}$ The Third Circuit found that the claims by the Trustee against Merrill Lynch for securities fraud, RICO, and breach of fiduciary duty were noncore claims that the debtor could have pursued in the absence of bankruptcy. ${ }^{86}$ Those claims fell within an otherwise valid arbitration clause in the debtor's customer agreement with Merrill Lynch. Finding no compelling bankruptcy reason to override the FAA, the Third Circuit held that the lower court had no discretion to refuse to compel arbitration. $^{87}$

But the core/noncore distinction works only one way. Courts seem nearly unanimous that there is no discretion to deny arbitration of noncore claims if a valid arbitration clause applies. That does not mean, however, that courts necessarily have discretion to refuse to enforce valid arbitration clauses in core proceedings. A number of different tests have emerged as to when a court may refuse to enforce an arbitration agreement in a core proceeding.

\section{The Split on Arbitration of Core Claims}

A split has emerged among the Circuits as to when a bankruptcy court has discretion to refuse to enforce an arbitration agreement covering a core claim. The courts have analyzed this issue under Shearson/American Express v. McMahon, Inc. ${ }^{88}$ the case in which the Supreme Court held that claims under the Securities Exchange Act of 1934 and RICO were arbitrable. The McMahon Court was responding to the holding in Wilko v. Swan that claims under the Securities Act of 1933 were not arbitrable. By the time the Court decided McMahon, the arc of arbitration law had moved unambiguously away from the Wilko approach. The

\footnotetext{
${ }^{85}$ Hays \& Co. v. Merrill Lynch, Pierce, Fenner \& Smith, Inc., 885 F.2d 1149, 1153 (3d Cir. 1989) (holding "trustee's section 544(b) claims are not arbitrable under the arbitration clause because they are not derivative of the debtor and the trustee is accordingly not bound by the Customer Agreement with respect to them").

${ }^{86}$ Id. at $1156 \mathrm{n} .9$ ("The non- $\$$ 544(b) claims made by Hays involve non-core proceedings because they do not involve: the administration of the estate; the allowance of claims against the estate; the voidance of preferences or fraudulent transfers; determinations as to dischargeability of debts; priorities of liens; or confirmation of a plan, etc.").

${ }^{87}$ Id. at 1156-57 ("[T]he district court lacked the authority and discretion to deny enforcement of the arbitration clause unless Hays had met its burden of showing that the text, legislative history, or purpose of the Bankruptcy Code conflicts with the enforcement of an arbitration clause in a case of this kind, that is, a non-core proceeding brought by a trustee to enforce a claim of the estate in a district court.").

${ }^{88} 482$ U.S. 220 (1987).
} 
Court was ready to find federal statutory claims arbitrable, and it needed a framework that would make that possible. It created a test designed to determine when a federal statute creating a right of action precluded the arbitration of claims based on that right of action. The Court concluded:

[T] he Arbitration Act's mandate may be overridden by a contrary congressional command. The burden is on the party opposing arbitration, however, to show that Congress intended to preclude a waiver of judicial remedies for the statutory rights at issue. If Congress did intend to limit or prohibit waiver of a judicial forum for a particular claim, such an intent "will be deducible from [the statute's] text or legislative history," or from an inherent conflict between arbitration and the statute's underlying purposes. ${ }^{89}$

The Court held that neither the Securities Exchange Act nor RICO demonstrated a Congressional intent to prohibit waiver of a judicial forum, and so held the claims arbitrable. It is worth noting that, to date, the Supreme Court has never found its McMahon test satisfied. In other words, the Court has never held that a statute was intended to prohibit arbitration.

Lower courts in bankruptcy cases have used the McMahon language to create a test for when a court has discretion to refuse to enforce an arbitration clause applicable to a core claim in bankruptcy. They treat the question as one of a clash between the FAA and the Bankruptcy Code, and purport to determine whether Congress intended to preclude arbitration of core matters. Two similar but slightly different tests have emerged in the Circuit Courts.

The Third and Fifth Circuits have held that a bankruptcy court has discretion to refuse to enforce an arbitration clause if the proceedings are based on Bankruptcy Code provisions and arbitration would inherently conflict with the purposes of the Code.$^{90}$ So, for example, in Mintze v. American Financial Services, Inc. (In re Mintze), ${ }^{91}$ the debtor had entered into a home equity loan agreement that contained an arbitration clause. The debtor filed for bankruptcy under chapter 13 and then, as DIP, sought to enforce a pre-petition rescission of the loan that she had asserted under the Truth in Lending Act and other state and federal consumer protection laws. ${ }^{92}$ The Third Circuit held that the bankruptcy court had no discretion to refuse to compel arbitration. The court found that, although this was a core proceeding,

\footnotetext{
${ }^{89}$ Id. at 226-27 (alteration in original) (citations omitted) (noting McMahon had to demonstrate Congress intended to bar Arbitration Act from applying to RICO and Exchange Act claims based on text and history of Arbitration Act).

${ }^{90}$ See Gandy v. Gandy (In re Gandy), 299 F.3d 489, 495 (5th Cir. 2002) (emphasizing bankruptcy court has discretion to refuse arbitration when cause of action is drawn from rights under Bankruptcy Code and noting it can consider if arbitration would help further goals of Bankruptcy Code).

91434 F.3d 222 (3d Cir. 2006).

${ }^{92} \mathrm{Id}$. at 226 (seeking pre-petition rescission of mortgage under Truth-in-Lending Act and other consumer protection laws because DIP alleged lender encouraged her to enter into illegal home equity loan).
} 
there was no inherent conflict between arbitration and the underlying purposes of the Bankruptcy Code, because the claims were not created by the Code. The mere fact that the decision on rescission would have an effect on the rights of other creditors was not sufficient ground to reject arbitration.

The Second and Fourth Circuits have adopted a test providing an additional basis for refusing to enforce an arbitration clause. They too hold that a court has discretion to refuse to enforce an arbitration agreement involving a core claim if the dispute is based on the Bankruptcy Code and arbitration would inherently conflict with the purposes of the Code. In addition, these courts have concluded that a court may refuse to enforce an arbitration agreement if "arbitration of the dispute would necessarily jeopardize the objectives of the Code..$^{93}$

In Philips v. Congelton (In re White Mountain Mining Co.), ${ }^{94}$ a Fourth Circuit case involving an international arbitration agreement, a dispute arose as to whether pre-filing advances made to the debtor company constituted loans or contributions to capital. One of the interested parties argued that this issue should be decided in arbitration. The bankruptcy court refused to compel arbitration and held a trial on the issue, after which it determined that the advances were loans. The Fourth Circuit affirmed, finding that, even though the claims were not created by bankruptcy law, this was a core proceeding because it involved the "allowance or disallowance of claims against the estate." ${ }^{195}$ It then found an inherent conflict between arbitration and the purposes of the Bankruptcy Code due to the importance of centralized decisionmaking in a chapter 11 case to protect reorganizing debtors and their creditors from piecemeal litigation. ${ }^{96}$

The result of these approaches is that very little clear guidance exists as to when an arbitration agreement should be enforced in bankruptcy. The various tests are so vague and malleable that they give courts license to do almost anything they want. Anecdotal evidence suggests that bankruptcy judges routinely enforce arbitration agreements, for both noncore and core claims, as a way to clear matters off the docket. But if so inclined, they seem to have fairly broad power to refuse to enforce arbitration, at least of core claims.

\footnotetext{
${ }^{93}$ MBNA Am. Bank, N.A. v. Hill, 436 F.3d 104, 109 (2d Cir. 2006). The Hill court enunciated this test, but held that the test was not satisfied in a case in which the DIP sued a creditor for violations of the automatic stay based on the creditor's post-petition withdrawal from the debtor's bank account. Id. The Second Circuit held that the bankruptcy court had no discretion to refuse to enforce an arbitration clause because arbitration did not inherently conflict with the Code or necessarily jeopardize the objectives of the Code. Id. (determining arbitration would not interfere with goals of Bankruptcy Code because resolution of claim did not affect bankruptcy estate and because claims were not directly connected to bankruptcy case).

${ }^{94} 403$ F.3d 164 (4th Cir. 2005).

${ }_{95} \mathrm{Id}$. at 169 (finding claim to be core proceeding because it related to estate administration).

${ }^{96} \mathrm{Id}$. at 170 (rationalizing arbitration would interfere with debtor's ability to reorganize because it would reduce confidence in debtor, cause estate to incur more expenses, and make it harder to acquire additional funding).
} 


\section{Academic Proposals for Reform}

Several scholars have offered proposals to simplify and clarify this body of law. One argument is that arbitration clauses should be considered executory contracts, because the arbitration agreement obligates the parties to a future performance--the participation in arbitration. As executory contracts, arbitration clauses would then be assumable or rejectable, in the discretion of the Trustee or DIP. This treatment would provide a straightforward solution to the problem of arbitration clauses in bankruptcy: the Trustee or DIP could simply assume or reject the arbitration agreement depending on whether arbitration seemed more favorable for the estate than resolution of the dispute by the bankruptcy court.

The difficulty with that approach, however, is that executory contracts must be assumed or rejected in whole. The Trustee or DIP may not assume some provisions of a contract while rejecting others. Arbitration agreements rarely stand alone. They almost invariably appear as part of other agreements. Consequently, a Trustee or DIP cannot treat the arbitration clause differently from the rest of the contract (by assuming the underlying contract and rejecting the arbitration clause, for example), unless the arbitration agreement is considered an entirely separate contract.

Several commentators have argued that arbitration agreements should be considered entirely separate from the principal contracts in which they appear. This argument rests on Prima Paint Corp. v. Flood \& Conklin Mfg. ${ }^{97}$ In Prima Paint, the Supreme Court held that arbitration clauses are separable from the agreements in which they are contained, for purposes of challenges to the enforceability of the underlying obligations. Thus, when a party to a contract containing an arbitration clause alleges that the principal agreement was procured by fraud, this allegation does not taint the arbitration agreement. A district court should send the dispute to an arbitrator to decide the fraud claim unless the party alleges that the arbitration clause itself was procured by fraud. Commentators have extrapolated from that conclusion to argue that arbitration agreements should be considered independent executory contracts for purposes of assumption or rejection under the Bankruptcy Code ${ }^{98}$ This approach would give Trustees and DIPs de facto control over the enforcement of arbitration clauses.

While this theory has some logical attraction, it seems unlikely to gain much purchase in the courts. Courts seem to agree with the basic principle of separability in bankruptcy cases, but the reported decisions use the separability analysis in a very different way. For example, In Societe Nationale Algerienne v. Distrigas

\footnotetext{
${ }^{97} 388$ U.S. 395 (1967).

${ }^{98}$ See Jason S. Brookner \& Monica S. Blacker, The Rejectability of Arbitration Clauses, 26 AM. BANKR. INST. J. 1, 77 (April 2007) ("The reciprocal future obligation [of the arbitration clause] would appear to make the arbitration clause executory and would thus subject arbitration clause to independent assumption or rejection.").
} 
Corp. ${ }^{99}$ the DIP rejected the underlying contract and the counterparty moved to enforce the arbitration agreement to determine its damages as a result of the rejection. The DIP opposed arbitration. The bankruptcy court held that the arbitration agreement was a separate contract and enforced it upon the counterparty's motion, sending the dispute to an international arbitration panel. ${ }^{100}$ Similarly, in In re Statewide Realty Co. ${ }^{101}$ the DIP rejected the underlying contract and then the counterparty sought to enforce an arbitration agreement to determine damages. Without expressly considering the separability issue, the court held that arbitration clause was enforceable despite rejection of underlying agreement.

No court has held that a Trustee or a DIP may assume or reject arbitration clauses at will, regardless of whether arbitration clauses are considered freestanding agreements. It may yet happen, but given the strong policy favoring arbitration, especially in international agreements, courts seem unlikely to turn this issue over to the discretion of Trustees and DIPs.

Another significant proposal for reform was suggested by Professor Alan Resnick, who has argued for a legislative solution to provide greater certainty and reduce the cost of litigation and appeals. ${ }^{102}$ Arguing that the McMahon analysis provides insufficient guidance to courts, he contends that the simplest solution is to focus on the core/noncore distinction. He proposes an amendment to the Bankruptcy Code providing that "contractual arbitration clauses are unenforceable in core proceedings, regardless of whether the proceeding involves causes of action derived from the debtor or bankruptcy actions that the Bankruptcy Code has created for the benefit of creditors or the estate." 103 In other words, he would remove all core proceedings from the ambit of arbitration. He would adhere to the existing principle that noncore proceedings are generally arbitrable. ${ }^{104}$ In Professor Resnick's

${ }^{99} 80$ B.R. 606, 609 (D. Mass. 1987) (describing conflict between debtor's rejection of contract after entering into chapter 11 and injured party's attemptto have breach of contract damages determined through international arbitration as set out in rejected contract).

${ }^{100} \mathrm{Id}$. at 613 (deciding as "representative of the American business community," debtor must "honor its bargain and proceed with international arbitration"). The court explained why the DIP opposed arbitration:

Measuring the damages by the benefit-of-the-bargain, [the creditor] claims 1.2 billion dollars. While the DIP could never satisfy such an enormous award, were one to be made, the DIP is the wholly owned subsidiary of [Cabot Cabot \& Forbes] and [the creditor] seems to believe that it may be better able to lift the corporate veil in an international forum than here at home. For its part, the DIP prefers to remain veiled before a known Bankruptcy Judge rather than endure the uncertainties of an international tribunal of 'three foreigners.

Id. at 607 n.2.

${ }^{101} 159$ B.R. 719,719 (D. N.J. 1993) (detailing chapter 11 debtor's rejection of management agreement and finding arbitration clause still effective if not contrary to Bankruptcy Code purposes or provisions).

${ }^{102}$ See Resnick, supra note 43, at 213 (arguing "Congress should amend the bankruptcy-related provisions of the judicial code").

${ }^{103} \mathrm{Id}$. at 214 (acknowledging an interest of justice exception).

${ }^{104}$ See id. at 218 (opining arbitration of core proceedings may implicate rights of third parties who have "not consented to arbitration" while non-core matters involve rights "created" outside of the Bankruptcy Code, are "derivative of the debtor," and are thus arbitrable). 
view, drawing a relatively bright line between core and noncore proceedings would have the salutary effect of centralizing bankruptcy proceedings while allowing all parties in interest an opportunity to be heard. ${ }^{105}$

These proposals for reform are meant to offer routes out of the bramble bush created by the courts analyzing arbitration agreements in bankruptcy through the lens of McMahon. They would greatly simplify matters. Professor Resnick's proposal in particular may well prove to be the most workable approach, because it has the benefit of being easy for courts to understand and put into practice. But I believe there is an alternative way of looking at the issue that gives greater effect to the policy supporting arbitration, while still protecting the integrity of the bankruptcy process. It begins with a rethinking of McMahon.

\section{B. The Limited Scope of McMahon}

McMahon needs to be viewed in the context in which it was handed down. The Supreme Court was facing a precedent almost directly on point-Wilko-that had outlived its usefulness. The Court was ready to hold that claims founded on federal statutes were arbitrable even in cases not involving international disputes. Wilko strongly suggested they were not, on the ground that rights created by federal law should be enforced through public adjudication and not through private arbitration. To deal with that conflict, the Court enunciated the McMahon test, focusing on whether Congress demonstrated an intent in a given statute to preclude private arbitration. Since no federal statute expressly referred to arbitration-much less expressly prohibited it this gave courts carte blanche to enforce arbitration agreements in virtually any context. And in fact, it is widely assumed now that any claim is potentially arbitrable. McMahon was a vehicle to expand the scope of arbitration, not to contract it.

More importantly, McMahon addressed a relatively specific question. The Court understood its inquiry to address whether Congress intended to preclude arbitration of a "claim founded on statutory rights." 106 That is, the Court addressed the situation in which a federal statute creates a right of action, as the Securities Exchange Act creates a right of action for securities fraud and RICO creates a right of action for a variety of fraud-related misdeeds. The Court then evaluated whether that kind of claim could appropriately be heard by an arbitrator. The case is about whether a claim founded on a federal statute is arbitrable. It says nothing at all

\footnotetext{
${ }^{105} \mathrm{Id}$. at 216 (stating rule is consistent with fundamental principle which states agreements to arbitrate must be based on parties' consent because consent is key element of enforceable contractual arbitration provision). Professor Resnick's proposal would further promote efficiency by limiting appeals of the arbitration enforcement determination. He suggests granting only one layer of appeal- to the district court or bankruptcy appellate panel-made on an abuse-of-discretion standard. Id. at 219.

${ }^{106}$ Shearson/Am. Express Inc. v. McMahon, 482 U.S. 220, 226 (1987) (stating complaint alleged violation of section 10(b) of Exchange Act and RICO claim, 18 U.S.C. $\$ 1962$ (c) (2000), "by engaging in fraudulent, excessive trading on respondents' accounts and making false statements and omitting material facts from advice given to respondents").
} 
about whether some other forum would be more appropriate for any particular claim. That is, the case tells us how to determine whether a particular statutorilycreated cause of action may be pursued in arbitration. It does not tell us how to determine which among several possible forums is the best for hearing a cause of action that could be arbitrated.

Most of the reported decisions raising questions about arbitration in bankruptcy involve claims that are undeniably arbitrable. Some of the most common involve securities fraud, RICO, common-law fraud, breach of contract, and avoidance of fraudulent conveyances. These claims are all arbitrable. McMahon and its test of arbitrability have long since been satisfied with respect to these causes of action.

To be sure, there are some claims raised in bankruptcy for which McMahon is a relevant precedent. For example, preference actions are founded on a federal statute-they do not exist except as provided by the Bankruptcy Code. A court deciding in the first instance whether a preference action is arbitrable should properly consider the McMahon test. Perhaps the Supreme Court will one day address that question and hold that preference actions are not arbitrable. But given what we know about the Supreme Court's predilection for arbitration, that seems an extremely unlikely outcome. The Court has given no indication that it believes anything is beyond the reach of arbitration. And no lower court facing that issue has ever held that preference actions are not arbitrable.

Lower courts have used McMahon as a vehicle to give them the discretion to decide in particular cases whether to enforce an arbitration clause or not. That kind of analysis pushes McMahon well beyond its holding. McMahon provides a test to determine whether a claim founded on a federal statute is arbitrable. It does not provide a test to allow bankruptcy courts to decide whether an arbitrable claim would be better heard in bankruptcy court.

Furthermore, nothing in the Federal Arbitration Act gives a court that kind of discretion. The FAA provides that a written arbitration agreement "shall be valid, irrevocable, and enforceable, save upon such grounds as exist at law or in equity for the revocation of any contract." ${ }^{107}$ If a claim is arbitrable and is covered by a written arbitration agreement, a court must enforce the agreement unless some legal defense applicable to contracts in general would allow for the revocation of the agreement to arbitrate. There are several principles of bankruptcy law that apply to any contract and could provide a ground for refusing to enforce an arbitration agreement. Most important is the Trustee or DIP's power to assume or reject executory contracts. Again, several commentators have argued that arbitration agreements are executory contracts that may be assumed or rejected. This argument has logical force and comports with the language of the FAA. It may at some point find acceptance in the courts. To date, however, it has not been adopted. Under current law, there is no basis for bankruptcy courts to pick and choose which arbitration clauses to enforce.

${ }^{107} 9$ U.S.C. $§ 2(2000)$. 
But this does not mean bankruptcy courts are powerless when they encounter arbitration clauses. In fact, they have a great deal of power to use arbitration to further bankruptcy's goals. And they can do that while also upholding the goals of arbitration law.

\section{RECONCEPTUALIZING THE PROBLEM OF ARBITRATION IN BANKRUPTCY}

Courts considering the intersection of arbitration and bankruptcy have tended to see the problem as one of forum selection. They ask whether it is more appropriate for matters affecting a pending bankruptcy to be heard in an arbitral forum or in a bankruptcy forum. In effect, they treat arbitrators as quasi-courts with the power to decide cases in ways that compromise the bankruptcy process. They conclude that the only way to protect bankruptcy is to prevent the arbitration process from going forward in cases with the potential to significantly impact the bankruptcy proceedings.

This approach reflects a misunderstanding of arbitration and a lack of emphasis on the real interests to be protected in bankruptcy. Arbitration is a private mechanism for resolving contractual disputes. It is not a formal, quasi-judicial dispute resolution process in competition with bankruptcy. It has significant flexibility that, if utilized, can make arbitration a useful and positive component of a rational bankruptcy scheme, and one that does not compromise bankruptcy's goals.

The key to my reconceptualization is to focus on the underlying concerns that animate courts' reluctance to embrace arbitration in bankruptcy. These boil down to two. First, courts are concerned about cost and delay. Bankruptcy is designed to move quickly-more quickly than traditional civil litigation. Delays and unnecessary detours potentially harm both the debtor, who is looking to move forward, and the creditors, who are awaiting an ever-diminishing return. Perfection is often the enemy of the good, and in bankruptcy this is especially true. Hence, bankruptcy judges have the power to estimate the value of claims if precise determination would consume undue time and resources.

Second, courts worry about the potential for decisions made in arbitration to skew the bankruptcy process by favoring one creditor over others. This is partly a substantive concern-a creditor should not receive more than its fair share-but also reflects concerns about process, specifically a reluctance to allow decisions affecting the estate to be made without the input of other creditors.

The first of those concerns implicates arbitration at the initial enforcement stage. The damage from undue cost or delay is inflicted simply by going through with arbitration, regardless of outcome. The law of arbitration already contains a mechanism to avoid that kind of harm. The Supreme Court has held that an 
arbitration agreement need not be enforced if the costs of arbitration would prevent a party from effectively vindicating its statutory rights. ${ }^{108}$

The second concern implicates the award and its enforcement. It is a concern about the potential for awards to handcuff bankruptcy courts to the detriment of the bankruptcy process. This is really a concern about finality and judicial review. Arbitration law also provides mechanisms to deal with this concern, but they are less certain and require more elaboration.

\section{A. Denying Enforcement of Arbitration Agreements to Prevent Unnecessary Expense or Delay}

Courts currently have discretion to refuse to enforce arbitration agreements where the arbitration is structured in such a way that, as a practical matter, a party will not be able to effectively vindicate its legal rights. That principle comes from the Supreme Court's decisions upholding arbitration of statutory claims based on a finding that arbitration would allow the claimants to effectively vindicate their statutory rights. While the Supreme Court has never refused to enforce an arbitration agreement on those grounds, it contemplated that possibility in Green Tree Financial Corp.-Alabama v. Randolph. ${ }^{109}$ Randolph involved an arbitration clause in a consumer credit agreement. Randolph, the consumer, argued that the agreement should be held unenforceable because it was silent as to the costs of arbitration, creating a risk that she would not be able to enforce her statutory rights under the Truth in Lending Act through arbitration. ${ }^{110}$ The Supreme Court held that the arbitration clause was valid and enforceable. Although the Court stated that "[i]t may well be that the existence of large arbitration costs could preclude a litigant such as Randolph from effectively vindicating her federal statutory rights in the arbitral forum," the Court found nothing in the record to show that the consumer would bear those costs. ${ }^{111}$

Lower courts applying Randolph have supplied a variety of tests to determine whether the costs of arbitration would prevent a claimant from pursuing statutory rights. ${ }^{112}$ One leading case is Bradford v. Rockwell Semiconductor Sys., ${ }^{113}$ a case addressing a challenge to an arbitration clause in an employment agreement. The Fourth Circuit in Bradford established a test based on the Randolph language: "We believe that the appropriate inquiry is one that evaluates whether the arbitral forum

\footnotetext{
${ }^{108}$ See Green Tree Fin. Corp.-Ala. v. Randolph, 531 U.S. 79, 92 (2000) (reciting respondent purchased mobile home financed through petitioner and agreement provided that all disputes arising from contract, whether arising under case law or statutory law, would be resolved by binding arbitration).

${ }^{109} \mathrm{Id}$. at 92 (finding respondent did not meet burden of showing arbitration would be prohibitively expensive).

${ }_{10}^{10} \mathrm{Id}$. at 90.

${ }^{111} I d$.

112 See generally Dan O'Hearn, Beyond "Let Them Eat Cake": An Argument for the Armendariz Method of Cost Allocation in Mandatory Employment and Consumer Arbitration, 2007 J. DISP. RESOL. 541 (2007) (analyzing case law applying Randolph).

113238 F.3d 549 (4th Cir. 2001).
} 
in a particular case is an adequate and accessible substitute to litigation, i.e., a caseby-case analysis that focuses, among other things, upon the claimant's ability to pay the arbitration fees and costs, the expected cost differential between arbitration and litigation in court, and whether that cost differential is so substantial as to deter the bringing of claims." ${ }^{114}$ In effect, the Bradford test measures, on a case-by-case basis, the costs a claimant would incur in arbitration against the costs she would incur in litigation, and then factors in the claimants ability to pay.

The Sixth Circuit employed a similar test in another leading case, Morrison $v$. Circuit City Stores, Inc. ${ }^{115}$ Echoing Bradford, the Morrison court held that "[r]eviewing courts must consider whether the [arbitrators' fees], ... taken together with the other costs and expenses of the differing fora, would deter potential litigants from bringing their statutory claims in the arbitral forum." ${ }^{116}$ But the court then added to the Bradford test by asking whether expenses of the kind in question would deter similarly situated litigants from pursuing their claims. ${ }^{117}$ The court held the arbitration agreement in that case unenforceable as imposing inordinate costs on the claimant, and in the process hinted the cost-splitting provisions in employment arbitration agreements would frequently create an excessive burden for all but highly-compensated employees. ${ }^{118}$

The cost calculus is a little different in bankruptcy than in ordinary civil litigation, but the basic idea is the same. The Trustee or DIP in bankruptcy acts on behalf of both the debtor and the creditors to vindicate a variety of statutory rights protected by the Bankruptcy Code. For both the debtor and creditors, expedience is essential to the effective vindication of those rights. Money spent on tangential dispute resolution is money not available to pay creditors. Time spent that delays the resolution of the bankruptcy is time in which the debtor cannot move forward and the value of the estate erodes.

Where bankruptcy is different, however, is in how litigation expenses are paid. The costs of litigation are a component of the administrative expenses given priority in the bankruptcy estate. Unlike a civil plaintiff who may lack the resources to pursue a claim in arbitration and may therefore choose to suffer an uncompensated loss, the Trustee or DIP has a source of funds for litigation expenses and a duty to pursue claims on behalf of the estate or to defend claims against the estate. Consequently, it is much less likely that a Trustee or DIP would actually be deterred from pursuing a claim because of cost. For that reason, the focus in cases like Bradford and Morrison on the claimants' means and the likelihood that the claimant would actually not pursue the claim does not fit comfortably in the bankruptcy context. But if arbitration would, in a given case, unnecessarily deplete the assets

\footnotetext{
${ }^{114} I d$. at 556.

115317 F.3d 646 (6th Cir. 2003) (en banc).

${ }^{116} I d$. at 664 .

${ }^{117}$ Id. (allowing potential litigants to show arbitration costs are high before arbitration occurs).

${ }^{118} I d$. at $669-70$. (articulating arbitration is more expensive than litigation in court and will deter similarly situated employees from bringing Title VII claims against employer).
} 
of the estate, that should provide grounds for refusing to enforce an arbitration agreement. ${ }^{119}$

In ordinary civil litigation, courts have refused to enforce arbitration agreements in which the agreement provides for an allocation of fees that would have the effect of imposing costs on arbitration claimants that would exceed the court costs they would face if pursuing the same claim in court. ${ }^{120}$ The principle is that arbitration should not put an extra burden on claimants seeking to enforce statutory rights. The calculus is a little different in bankruptcy, but the basic idea is the same. The Trustee or DIP in bankruptcy acts on behalf of both the debtor and the creditors to vindicate a variety of statutory rights. For both the debtor and creditors, expedience is essential to the effective vindication of those rights. Money spent on tangential dispute resolution is money not available to pay creditors. Time spent that delays the resolution of the bankruptcy is time in which the debtor cannot move forward and the value of the estate erodes. If arbitration would cause undue cost or delay impairing the Trustee's or DIP's ability to protect rights of the debtor or creditors, that should provide grounds for refusing to enforce an arbitration agreement. ${ }^{121}$

Phillips v. White Mountain Mining Co. (In re White Mountain Mining Co. $)^{122}$ is an example of how cost and efficiency concerns could negate the policy in favor of arbitration. As described above, In re White Mountain involved a dispute over the characterization of cash advances made to the debtor prior to bankruptcy. The party who made the advances claimed they were loans rather than contributions to capital, and sought enforcement of an arbitration agreement with the debtor that called for arbitration in London. ${ }^{123}$ The Fourth Circuit refused to enforce the arbitration agreement, in part because the debt-equity issue was key to formulating a plan of reorganization and arbitration in a foreign country would impose unacceptable costs in terms of delay, uncertainty, and additional financial burdens. ${ }^{124}$

A court deciding whether to enforce an arbitration clause in a situation such as the one in In re White Mountain could conclude that arbitration would impair the parties' ability to vindicate their statutory bankruptcy rights. It could refuse to compel arbitration on that ground. This approach would give appropriate deference

${ }^{119}$ Cf. Ins. Co. of N. Am. v. NGC Settlement Trust \& Asbestos Claims Mgmt. Corp., (In re Nat'l Gypsum Co.), 118 F.3d 1056 (5th Cir. 1997). In National Gypsum, the Fifth Circuit rejected the Bankruptcy Court's conclusion that it had the discretion to refuse to compel arbitration of a core proceeding on the ground that the Bankruptcy Court was a more efficient forum than arbitration. The Fifth Circuit concluded that McMahon provided the only grounds for refusing to compel arbitration, and implied that efficiency alone may not be a valid ground under McMahon. Id. at $1070 \mathrm{n} .21$. My contention is that the reliance on McMahon is misplaced, and so that conclusion should not be considered controlling.

${ }^{120}$ See Phillips v. Assocs. Home Equity Servs., Inc., 179 F. Supp. 2d 840, 846 (N.D. Ill. 2001) (refusing to enforce arbitration clause in consumer contract where arbitration would cost at least twelve times more than filing case in federal court).

${ }^{121}$ Cf. In re Nat'l Gypsum Co., 118 F.3d at 1067 (refusing to arbitrate claims where arbitration process had not yet started and Bankruptcy Court noted it was efficient and effective forum to resolve bankruptcy issues).

${ }_{122} 403$ F.3d 164 (4th Cir. 2005).

${ }^{123} \mathrm{Id}$. at 167.

${ }^{124}$ Id. at $169-70$. 
to the arbitration agreement, while ensuring that arbitration does not compromise the rights conferred by the Bankruptcy Code.

For this approach to work in practice, however, a modification of the procedure for challenging arbitration agreements on cost grounds would probably be required. A significant hurdle for ordinary litigants seeking to avoid arbitration on grounds of excessive cost is the burden of proof imposed by the Supreme Court in Randolph. The Court held that "where, as here, a party seeks to invalidate an arbitration agreement on the ground that arbitration would be prohibitively expensive, that party bears the burden of showing the likelihood of incurring such costs." ${ }^{125}$ The Court refused in Randolph to invalidate the arbitration agreement because the claimant could not produce evidence that the costs of arbitration would prevent her from vindicating her rights.

That allocation of the burden of proof does not necessarily have to remain in effect when a bankruptcy Trustee or DIP challenges an arbitration agreement. In other contexts, bankruptcy shifts burdens of proof in order to protect the estate. For example, under section 547 of the Code, the Trustee or DIP may avoid transfers made by an insolvent debtor 90 days prior to the filing. Section 547 creates a presumption that the debtor was insolvent on and during the 90 days immediately preceding the date filing. ${ }^{126}$ This has the effect of putting the burden of production on the party defending the preference action to produce evidence that the debtor was solvent. The ultimate burden of proof on the solvency issue falls on the Trustee or DIP, however. ${ }^{127}$ The shift in burdens of proof is even more dramatic where a Trustee seeks to avoid unauthorized post-petition transfers affecting the estate. Even though the Trustee must affirmatively avoid the conveyance in an adversary proceeding, the party claiming that the transfer was valid bears the burden of proof on that issue. ${ }^{128}$

As those examples demonstrate, the need to protect the estate justifies modifying traditional burdens of proof on a variety of issues raised in bankruptcy. A fairly small leap would be required to conclude that a different burden of proof should also apply when a Trustee or DIP seeks to show that arbitration would unduly impair the rights of the debtor or creditors. Furthermore, a Trustee or DIP in bankruptcy should be afforded more deference than a typical litigant in showing that arbitration would impose undue costs. The Trustee or DIP acts as a quasipublic official under the supervision of the United States Trustee, with obligations not just to the debtor and creditors, but to the court. A judgment by the Trustee or DIP that arbitration would impair the effective vindication of the rights protected by

\footnotetext{
${ }^{125}$ Green Tree Fin. Corp.-Ala. v. Randolph, 531 U.S. 79, 92 (2000) (deciding issue of enforceability of binding arbitration agreement covering all statutory claims when agreement failed to allocate costs of arbitration).

${ }^{126} 11$ U.S.C. $\$ 547$ (f) (2006) ("[T] he debtor is presumed to have been insolvent on and during the 90 days immediately preceding the date of the filing of the petition.").

${ }^{127}$ See 5 COLLIER, supra note 19, at 547-39 (indicating burden of proof of insolvency is on trustee).

${ }^{128}$ See FED. R. BANKR. P. 6001 ("Any entity asserting the validity of a transfer under $\$ 549$ of the Code shall have the burden of proof.").
} 
bankruptcy law should not be dismissed out of hand, even if backed by limited evidence.

These points suggest that a modified burden of proof regime would be appropriate for challenges to arbitration agreements lodged by Trustees or DIPs. Perhaps the Trustee or DIP should have an initial burden of producing some evidence that arbitration would impose undue costs on the estate in the form of expenses or delay. Then the party seeking arbitration might have the burden of persuasion to show that the costs are unduly high. Or the burden could be put on the third-party seeking arbitration right from the outset to demonstrate that the costs are reasonable. No change in the burden of proof should be applied when the Trustee or DIP wants arbitration and is opposed by the third-party.

Allowing Trustees and DIPs to challenge arbitration clauses on cost grounds would have the effect of promoting expeditious arbitration in cases arising in the context of bankruptcy. The arbitration providers could easily respond to that need by creating protocols for arbitration of bankruptcy-related matters. I will suggest how those might work later in this article. But first, I will explore how bankruptcy courts can protect the bankruptcy process at the back end of arbitration, when the time comes to enforce an award.

\section{B. The Treatment of Arbitral Awards in Bankruptcy: A Contractarian Approach}

The potential for the arbitration process to impair the rights of the debtor and the creditors because of excessive delay and cost can be addressed at the stage of enforcement of the arbitration clause, in the manner just described. The potential for an arbitration award to skew the recovery available to creditors not involved in the arbitration is best addressed at the stage of enforcement of the arbitration award. The bankruptcy court (or district court) needs to have a mechanism to ensure that the award does not compromise the rights and interests that the bankruptcy process is designed to protect.

This is almost exclusively a concern arising when an award is rendered against a Trustee or DIP. When a Trustee or DIP arbitrates a claim against a creditor or other third-party and wins, enforcement is straightforward. Assuming the arbitration agreement provided in writing that the award be entered as a judgment, the Trustee or DIP may apply to a district court to enter the award as a judgment and then may collect on it on behalf of the estate ${ }^{129}$ Concerns arise when an award is entered against a Trustee or DIP. That award becomes a claim against the estate, just like any other unsecured debt. The claimant stands in line with other unsecured creditors, and is entitled only to a pro rata share of the estate after priority creditors are paid. The potential problem is that the award may skew the creditor's pro rata share. If the award is excessive, it will have the effect of privileging that creditor

\footnotetext{
${ }^{129}$ See 9 U.S.C. $\$ 9(2000)$ ("If parties in their agreement have agreed that a judgment of the court shall be entered upon the award made pursuant to the arbitration, . . . any party to the arbitration may apply to the court ... for an order confirming the award, and thereupon the court must grant such an order ....").
} 
over others. The issue then becomes the extent to which the bankruptcy court is bound to accept the award. This is a problem, in other words, of judicial review of arbitral awards.

\section{Judicial Review of Arbitral Awards}

In normal circumstances, an arbitrator's award has a degree of finality that almost no judgment of a trial-level court-even a bankruptcy court-has. At least one level of review exists for virtually any court judgment. That is not the case for arbitral awards. Courts normally have very little room to review awards in arbitration. Section 10 of the FAA contains a list purporting to cover the four exclusive grounds for vacating arbitral awards:

(1) where the award was procured by corruption, fraud, or undue means;

(2) where there was evident partiality or corruption in the arbitrators, or either of them;

(3) where the arbitrators were guilty of misconduct in refusing to postpone the hearing, upon sufficient cause shown, or in refusing to hear evidence pertinent and material to the controversy; or of any other misbehavior by which the rights of any party have been prejudiced; or

(4) where the arbitrators exceeded their powers, or so imperfectly executed them that a mutual, final, and definite award upon the subject matter submitted was not made. ${ }^{130}$

In one way or another, these all embody concerns about arbitrator misconduct, in the form of partiality, corruption, or failure to act in accordance with arbitral norms. Notably absent is any provision for overturning an award because the arbitrator got the facts or the law wrong. Under the express terms of the FAA, courts must enforce arbitral awards unless there is evidence of arbitrator misconduct.

Nevertheless, courts have found several non-statutory grounds for vacating awards because of decisional errors committed by the arbitrator. The most widely invoked is the "manifest disregard of the law" standard first enunciated by the Supreme Court in dicta in Wilko. ${ }^{131}$ The courts have developed different formulations of the manifest disregard test. ${ }^{132}$ Most require evidence of a conscious

\footnotetext{
${ }^{130} 9$ U.S.C. $\$ 10(2000)$.

${ }^{131}$ Wilko v. Sawn, 346 U.S. 427, 436-37 (1953) ("[I]nterpretations of the law by the arbitrators in contrast to manifest disregard are not subject ... to judicial review for error in interpretation.").

${ }^{132}$ See Noah Rubins, "Manifest Disregard of the Law" and Vacatur of Arbitral Awards in the United States, 12 AM. REV. INT'L ARB. 363, 368-70 (2001) (asserting all federal circuit courts have adopted manifest disregard or a version of it, but Seventh Circuit decision in 2001 questions its continued acceptance); see also Kenneth R. Davis, When Ignorance of the Law Is No Excuse: Judicial Review of Arbitration Awards, 45 BUFF. L. REV. 49, 92-97 (1997) (stating manifest disregard has been interpreted to
} 
decision by the arbitrator to decide contrary to a clearly applicable governing rule, making the test extremely difficult to satisfy. ${ }^{133}$ Arbitration losers frequently seek judicial review on manifest disregard grounds, but those challenges are very rarely successful. ${ }^{134}$

The other main judicially-created ground for vacating an arbitral award is rooted in the contract doctrine of public policy. For years, courts uncomfortable with arbitration or simply looking for a way to monitor it vacated awards on the ground that the award violates public policy. ${ }^{135}$ But there was a great deal of confusion about the nature of the policy that had to be violated to justify vacatur, with courts often vacating awards based on generalized conclusions that the award contravened amorphous public policy goals. The Supreme Court gave some guidance on that issue in United Paperworkers International Union v. Misco, Inc., ${ }^{136}$ in which it upheld an arbitrator's award reinstating an employee of a manufacturing company who had been discharged for violating a company rule against possession of drugs on company property. ${ }^{137}$ The Court rejected a challenge to that award on public policy grounds. Although it conceded that allowing drug use on an industrial site might be a bad idea, it held that an award may be vacated only if it explicitly conflicts with a clear public policy "ascertained by reference to the laws and legal precedents and not from general considerations of supposed public interests." 138

mean different things including arbitrator understands or knows the law, but disregards or ignores it, and requiring "plenary review of legal errors arising out of statutory claims").

${ }_{133}$ See Merrill Lynch, Pierce, Fenner \& Smith, Inc. v. Jaros, 70 F.3d 418, 421 (6th Cir. 1995) ("[A]n arbitration panel does not act in manifest disregard of the law unless (1) the applicable legal principle is clearly defined and not subject to reasonable debate; and (2) the arbitrators refused to heed that legal principle."); see also Merrill Lynch, Pierce, Fenner \& Smith, Inc. v. Bobker, 808 F.2d 930, 933-34 (2d Cir. 1990) (emphasizing difficulty in reviewing arbitrator's award under manifest disregard because the allegedly ignored law "must be well defined, explicit, and clearly applicable").

${ }^{134}$ There are only a handful of reported circuit court decisions since 2000 vacating or affirming the vacatur of awards on manifest disregard grounds. See Hardy v. Walsh Manning Sec., L.L.C., 341 F.3d 126, 128-30 (2d Cir. 2003) (finding conflicting statements regarding liability of person under respondeat superior or as employee, therefore vacating and remanding based on manifest disregard); Nationwide Mut. Ins. Co. v. Home Ins. Co., 330 F.3d 843, 847 (6th Cir. 2003) (highlighting arbitration award attempting to "vest rights" in nonparticipant, third-party was done in manifest disregard for legal principle); Gas Aggregation Servs., Inc. v. Howard Avista Energy, LLC, 319 F.3d 1060, 1069 (8th Cir. 2003) (maintaining arbitration panel is in manifest disregard when citing relevant law precluding suit under Consumer Fraud Act by commercial trader and ignores it in ruling). During that period, at least 83 published district court opinions discussed manifest disregard as a grounds for vacating an award. Not one of them resulted in a vacatur. See Kirgis, supra note 1, at 104-05 \& n.30 (asserting courts rarely vacate rewards).

${ }^{35}$ See Ann C. Hodges, Judicial Review of Arbitration Awards on Public Policy Grounds: Lessons from the Case Law, 16 OHIO ST. J. ON DISP. RESOL. 91, 95-102 (2001) (detailing results of collection of cases starting in 1960 regarding use of public policy to challenge arbitration awards).

${ }^{136}$ (Misco) 484 U.S. 29 (1987).

${ }^{137} I d$. at 33 (noting employee told company he had been arrested in his home for drug possession, and three days later company learned employee had been involved in another marijuana incident on company property in someone else's vehicle). The arbitrator had refused to consider that evidence because it was discovered after the decision to terminate had been made. Id.

${ }^{138}$ Id. at 30 (quoting W.R. Grace and Co. v. Local Union 759, 461 U.S. 757, 766 (1983)) 
In Eastern Associated Coal Corp. v. United Mine Workers of America, ${ }^{139}$ the Court refined the public policy test further while refusing to vacate an award reinstating a truck driver who twice tested positive for marijuana. The Court addressed whether it was sufficient grounds for vacatur for an award to be "contrary to public policy as ascertained by reference to positive law," or whether the award must affirmatively "violate" positive law. ${ }^{140}$ Although the Court refused to adopt the latter standard as a firm rule, it emphasized the narrow scope of the public policy ground and suggested that it would be very rare for an award to warrant vacatur on public policy grounds without violating positive law. It concluded that the award at issue did not merit vacatur because neither Congress nor the relevant regulatory agencies had expressly prohibited an employer from allowing an employee who tested positive for drugs to remain on the job. ${ }^{141}$

Both Misco and Eastern Associated Coal are cases involving collective bargaining agreements, which technically are not covered by the FAA. Nevertheless, courts tend to treat labor arbitration cases as if they were governed by the FAA, as the Supreme Court explicitly recognized in Misco ${ }^{142}$ The decisions in these cases are instructive in interpreting the law of arbitration in other contexts. ${ }^{143}$ Together, they suggest an extremely narrow ground for public policy review of arbitral awards: An award may be vacated on public policy grounds only if a party can show that the award contravenes a specific rule of law.

Both of these grounds for review--manifest disregard and public policy-have been thrown into some doubt by the Supreme Court's recent decision in Hall Street Assocs., L.L.C. v. Mattel, Inc. ${ }^{144}$ In Hall Street, the Court held that the parties to an arbitration agreement did not have authority to modify the grounds for judicial review specified in sections $10 \& 11$ of the FAA. The court held that the statutory grounds provided in those sections are exclusive. It discussed the manifest disregard test, but did not expressly approve it or reject it. Instead, it suggested that manifest disregard might simply be another way of talking about certain of the

\footnotetext{
${ }^{139} 531$ U.S. 57 (2000).

${ }^{140}$ Id. at 63 (holding District Court "correctly articulated the standard" and asked whether award violated positive law instead of whether award was "contrary to public policy as ascertained by reference to positive law"); see also E.I. DuPont de Nemours \& Co. v. Grasselli Employees Indep. Assoc. of E. Chicago, Inc., 790 F.2d 611 (7th Cir. 1986) (Easterbrook, J. concurring) ("[T]he [FAA] restricts the court to ascertaining that the arbitrator was a faithful agent of the contracting parties.").

${ }^{141} I d$. at 66-67 (noting this award violates "no specific provision of any law" and "[n]either Congress nor the Secretary has seen fit to mandate the discharge of a worker who twice tests positive for drugs").

${ }^{142}$ See Misco, 484 U.S. at 40 n.9 ("[T]he federal courts have often looked to the [Federal Arbitration] Act for guidance in labor arbitration cases.").

${ }^{143}$ See Steven L. Hayford, Unification of the Law of Labor Arbitration and Commercial Arbitration: An Idea Whose Time Has Come, 52 BAYLOR L. REv. 781, 863 (2000) ("The Supreme Court now views the FAA as establishing a preemptive body of federal law strongly favoring the enforcement of contractual agreements to arbitrate. It sees commercial arbitration 'strictly as a matter of contract' and considers the role of the courts to be one of simply giving effect to the intent of parties who agree to arbitrate future disputes.").

${ }^{144} 552$ U.S. $576(2008)$.
} 
grounds for review contained in sections $10 \& 11$. The Court did not expressly discuss public policy review at all.

Regardless of Hall Street's treatment of manifest disregard and its language about the exclusivity of the grounds in sections 10-11, the kind of public policy review I espouse must be available to reviewing courts. The best way to understand how this type of review works is to think of arbitration in contractarian terms. There is a tendency, generally shared by bankruptcy courts, to view arbitration as a type of quasi-adjudication, with arbitrators deciding contested legal claims in an adversarial process one step removed from adjudication. That was the approach the Supreme Court adopted in Wilko, in which it refused to compel arbitration of claims under the Securities Act because of its fear that arbitrators would not apply the law properly. The Court in Wilko saw the arbitrators as judicial surrogates, and as untrustworthy surrogates.

As arbitration has gained wide acceptance in many different contexts, however, that quasi-adjudicatory model seems less and less apt. The transition began with Mitsubishi Motors Corp. v. Soler Chrysler-Plymouth, ${ }^{145}$ in which the Supreme Court enforced an international commercial arbitration agreement in a case raising claims under the antitrust laws. ${ }^{146}$ Paying lip service to the need for accurate determinations of statutory rights, the Supreme Court held the antitrust claims arbitrable. It concluded that the statutory rights at issue could be "effectively vindicated" in arbitration. ${ }^{147}$ In the following years, the Court enforced agreements to arbitrate claims under the securities laws, ${ }^{148}$ RICO, ${ }^{149}$ and the federal discrimination laws. ${ }^{150}$ These cases signaled an important shift in approach, as the Supreme Court simply stopped talking about the limits of arbitration as a mechanism for the adjudication of legal rights. The Court held parties to their contractual arrangements and sharply limited the lower courts' power to review awards.

The upshot of this trend is that arbitral awards are not treated as judgments subject to the usual requirements of due process. Regardless of the process used in the arbitration-and arbitration does increasingly resemble litigation, with its extensive discovery and motion practice-the award is given extreme deference by

${ }^{145} 473$ U.S. 614 (1985)

146 Id. at 624-25 (holding written agreements to arbitrate "valid, irrevocable, and enforceable" as centerpiece of Arbitration Act).

${ }^{147} I d$. at 636-37 (holding as long as litigants may effectively vindicate statutory causes of action in arbitral forum, arbitration will be appropriate).

${ }^{148}$ See, e.g., Rodriguez de Quijas v. Shearson/Am. Express, Inc., 490 U.S. 477, 482 (1989) (noting section 14 of The 1933 Act to be same in every respect to Securities Exchange Act of 1934 which Supreme Court has declined to read as prohibition to enforcement of "predispute agreements to arbitrate"); Shearson/Am. Express Inc. v. McMahon, 482 U.S. 220, 232 (1987) (holding arbitral tribunals to be competent way to resolve section 10(b) claims under Exchange Act).

149 See, e.g., id. at 242 (holding "RICO claim" arbitrable under Arbitration Act).

150 See, e.g., Gilmer v. Interstate/Johnson Lane Corp., 500 U.S. 20, 23 (1991) (stating claim under Age Discrimination in Employment Act is "subject[] to compulsory arbitration" pursuant to arbitration agreement). 
courts. That is consistent with a view of arbitration that considers the arbitration not as a form of quasi-adjudication, but as a form of contract. This approach was summarized by noted labor law scholar Ted St. Antoine:

[T] he arbitrator is the parties' officially designated "reader" of the contract. He (or she) is their joint alter ego for the purpose of striking whatever supplementary bargain is necessary to handle the anticipated unanticipated omissions of the initial agreement.... In sum, the arbitrator's award should be treated as though it were a written stipulation by the parties setting forth their own definitive construction of the labor contract. ${ }^{151}$

In other words, the arbitrator serves as the parties' agent, designated by them in advance to supply the terms of their agreement that they did not foresee and that are necessary to resolve a conflict between them. The award is thus not the equivalent of a judgment, with all the due process ramifications that would stem from that treatment. It is, instead, the equivalent of a contract term that must be enforced unless some legal rule renders it unenforceable.

This understanding informs the public policy ground of judicial review of arbitral awards. The award is treated as a contract term that the parties would have agreed upon ex ante had they foreseen the dispute. To prevail on a public policy challenge, a party must show that the award, if made a contract term, would have rendered the contract unenforceable as contrary to some provision of positive law.

As I suggested above, this kind of review must have survived Hall Street. ${ }^{152}$ It cannot be the case that an arbitrator has unreviewable power to order parties to violate positive law. ${ }^{153}$ Even if Hall Street were interpreted to eliminate an extrastatutory ground for public policy review, the same test should apply under the FAA, perhaps through the provision in section 10 allowing modification or vacatur "where the arbitrators exceeded their powers." ${ }^{154}$ A reviewing court should have the power to vacate an award that would have rendered the contract unenforceable if made a contract term.

\footnotetext{
${ }^{151}$ Theodore J. St. Antoine, Judicial Review of Labor Arbitration Awards: A Second Look at Enterprise Wheel and its Progeny, 75 MICH. L. REV. 1137, 1140 (1977).

152 But cf. Jonathan A. Marcantel, The Crumbled Difference Between Legal and Illegal Arbitration Awards: Hall Street Associates and the Waning Public Policy Exception, 14 FORDHAM J. CORP. \& FIN. L. 597 (2009) (concluding public policy ground for vacatur did not survive Hall Street, but also arguing courts should now adopt it as additional ground).

${ }^{153}$ See Richard C. Reuben, Building the Civilization of Arbitration: Personal Autonomy and Vacatur After Hall Street, 113 PENN ST. L. REV. 1103, 1143 (2009) ("The public policy exception is well-grounded and well-established, and nothing in the Hall Street opinion evinces an intent to eliminate it. It seems likely that courts will recognize a public policy exception to the seemingly strict rule of Hall Street, at least for illegal arbitration awards.").

${ }^{154} 9$ U.S.C. $\$ 10(4)(2000)$. The Supreme Court suggested in Hall Street that manifest disregard might be subsumed within section 10(4). See Hall Street Assocs., L.L.C. v. Mattel, Inc., 552 U.S. 576 (2008) (discussirig manifest disregard of law is yet another ground for vacatur).
} 
Whatever its source, case law or statute, the public policy ground for review is and should be a difficult standard to meet. In the context of the typical civil claim, public policy challenges to arbitral awards have rarely succeeded. Since the decision in Eastern Associated Coal, only a handful of reported cases have found public policy grounds sufficient to vacate awards, and most of those have come from state courts. ${ }^{155}$ But bankruptcy is different from ordinary civil litigation, in that a complex statutory scheme overlays the entire process and establishes a set of public policies that must be honored. It thus provides a basis for more extensive review of awards than would be permitted in the ordinary case. In particular, the public policies promoted by the Bankruptcy Code provide solid footing for more probing review of awards on public policy grounds.

\section{Bankruptcy Policy and Mandatory Rules}

An extensive academic debate surrounds the question of whether bankruptcy law should be considered a system of mandatory rules or of default rules. ${ }^{156}$ If bankruptcy law consists of mandatory rules, then parties may not contract around the Bankruptcy Code through pre-petition agreements. On the other hand, if bankruptcy law consists of default rules-like most state contract law-then parties may contract for alternative rules to apply in the event of insolvency; in other words, parties may opt out of the regime established by the Bankruptcy Code. A number of prominent bankruptcy scholars have argued that, for reasons of efficiency rooted in theories of law and economics, parties should be permitted to contract for their own bankruptcy rules. ${ }^{157}$

\footnotetext{
${ }^{155}$ See Chicago Fire Fighters Union Local No. 2 v. City of Chicago, 751 N.E.2d 1169, 1170-71, 1174 (IIl. App. Ct. 2001) (positing necessary "to consider public policy as a ground for vacating" arbitration award when arbitrator awarded reinstatement of firefighters who were discharged for having unauthorized party in firehouse); City of Brooklyn Ctr. v. Law Enforcement Labor Servs., Inc., 635 N.W.2d 236, 237-38 (Minn. Ct. App. 2001) (explaining arbitrator's award reinstating police officer terminated for engaging in pattern of sexual harassment will not be enforced because violates public policy); Buffalo Police Benevolent Ass'n v. City of Buffalo, 830 N.E.2d 308, 310 (N.Y. 2005) (stating arbitrator's award requiring Commissioner to select highest-ranking candidate was invalid because "[p]ublic policy does not permit a ruling that the Commissioner has given up his statutory power to choose the person he thinks best qualified" for position); Wash. County Police Officers' Ass'n v. Wash. County, 45 P.3d 515, 516 (Or. Ct. App. 2002) (explaining county's refusal to reinstate deputy who tested positive for marijuana, despite arbitration award ordering reinstatement, was valid on public policy grounds).

${ }_{156}$ See, e.g., Alan Schwartz, A Contract Theory Approach to Business Bankruptcy, 107 YALE L.J. 1807, 1809 (1998) (positing only "mandatory rules" in bankruptcy should be "structural rules"); Steven L. Schwarcz, Rethinking Freedom of Contract: A Bankruptcy Paradigm, 77 TEX. L. REV. 515, 516 (1999) ("[B]ankruptcy law should be viewed as default provisions and not as mandatory rules."); Marshall E. Tracht, Contractual Bankruptcy Waivers: Reconciling Theory, Practice, and Law, 82 CORNELL L. REV. 301, 344-45 (1997) (explaining efficiency of having certain bankruptcy provisions mandatory while permitting waiver of other provisions); Robert K. Rasmussen, Debtor's Choice: A Menu Approach to Corporate Bankruptcy, 71 TEX. L. REv. 51, 62-63 (1992) (arguing bankruptcy law should be treated as default rule).

157 See Elizabeth Warren \& Jay Lawrence Westbrook, Contracting Out Of Bankruptcy: An Empirical Intervention, 118 HARV. L. REV. 1197, 1204-07 (2005) (summarizing scholarship on "contractual" bankruptcy).
} 
The Code itself is, in general, silent on the question of whether a party may waive or alter its provisions through pre-petition contracts. In a handful of provisions, the Code expressly prohibits pre-petition waivers. For example, section 365 makes ipso facto clauses-clauses that terminate a contract in the event of the debtor's insolvency or bankruptcy-unenforceable. ${ }^{158}$ Under section 522, certain types of property, including the debtor's residence and car up to a certain value, are exempt from the bankruptcy estate; section 522(e) makes contracts waiving those exemptions unenforceable. ${ }^{159}$ The Code also limits debtors' ability to waive their dischargeability rights ${ }^{160}$ or their right to convert the bankruptcy from one chapter to another. ${ }^{161}$

But for the most part, the Code says nothing about whether its provisions may be waived or modified. And relatively little case law exists on the issue. To the extent courts have addressed whether bankruptcy law is a system of mandatory or default rules, the question has arisen primarily in the context of disputes over prepetition waivers of the automatic stay. ${ }^{162}$ There seems to be disagreement among the courts on this point, with some courts holding or suggesting that debtors may contract to waive the stay in certain circumstances, ${ }^{163}$ and others holding such waivers unenforceable. ${ }^{164}$

${ }^{158} 11$ U.S.C. $\$ 365(\mathrm{~b})(2)$ (2006) (stating clauses terminating contract do "not apply to a default that is a breach . . . relating to the insolvency ... . of the debtor at any time before the closing of the case [or] the commencement of a case under this title").

${ }_{159} 11$ U.S.C. $\S 522(\mathrm{e})(2006)$ ("[W]aiver of an exemption ... is unenforceable ... with respect to such claim against property . . . debtor may exempt under subsection (b) of this section.").

${ }^{160}$ See, e.g., 11 U.S.C. $\$ 524(\mathrm{c})$ (2006) (enumerating limited ways debt is dischargeable pursuant to agreement between holder of claim and debtor).

${ }^{161}$ See, e.g., 11 U.S.C. $\$ 706$ (a) (2006) ("[D]ebtor may convert a case under this chapter to a case under chapter 11,12 , or $13 \ldots$ if the case has not been converted under section 1112,1208 , or 1307 of this title. Any waiver of the right to convert a case under this subsection is unenforceable.").

${ }_{162}$ Typically, the provision in question obligates the debtor not to oppose a motion for relief from the stay. See Steven L. Schwarcz, Rethinking Freedom of Contract: A Bankruptcy Paradigm, 77 TEXAS L. REV. 515 , 524 (1999) ("Most of the decided cases have arisen in the context of clauses in loan agreements requiring debtors to waive the automatic stay in the event of their subsequent bankruptcy.").

${ }^{163}$ See In re Atrium High Point Ltd. P'ship, 189 B.R. 599, 607 (Bankr. M.D.N.C. 1995) (holding agreement not to oppose motion to lift stay appropriate because it was not part of original loan documents, but part of modification, and debtor received benefits); In re Jenkins Court Assocs. Ltd. P'ship, 181 B.R. 33, 36 (Bankr. E.D. Pa. 1995) (noting waiver of protection of automatic stay can be distinguished from traditionally invalid pre-petition agreements against bankruptcy filing); In re Powers, 170 B.R. 480, 482-83 (Bankr. D. Mass. 1994) (recognizing pre-petition agreements waiving opposition to relief from automatic stay can be enforceable, but are not self-executing. Motion for relief must also be made); In re Cheeks, 167 B.R. 817, 818-19 (Bankr. D.S.C. 1994) (holding pre-petition agreement was valid where agreement dismissed foreclosure action allowing debtor fresh start out of bankruptcy. To impose automatic stay as well would be inconsistent with policy against serial bankruptcy filings); see also In re Club Tower L.P., 138 B.R. 307, 311 (Bankr. N.D. Ga. 1991) (recognizing debtor only giving up single benefit of bankruptcy and not all benefits, "still retains benefits as to other creditors", and debtor already received benefits of automatic stay as creditor at issue has been stayed from enforcing rights under loan agreement); In re Citadel Ps., Inc., 86 B.R. 275, 276 (Bankr. M.D. Fla. 1988) (holding bad faith filing of bankruptcy gives cause for relief from automatic stay).

${ }^{164}$ See In re Pease, 195 B.R. 431, 433 (Bankr. D. Neb. 1996) ("[P]re-bankruptcy waiver of the automatic stay of 11 U.S.C. $\S 362$ is unenforceable, per se, because (1) the waiver is invalid due to debtor's lack of capacity to act on behalf of the debtor in possession; (2) the waiver is unenforceable under specific 
Despite the chorus of normative academic proposals for a contractual bankruptcy regime, however, and despite the disagreements among some courts regarding waivers of the automatic stay, the general consensus is that bankruptcy law is a system of mandatory rules. ${ }^{165}$ Code provisions establishing the automatic stay, allowing for the avoidance of preferences and fraudulent transfers, establishing priorities, setting exemptions, and providing for discharge are integral to the functioning of the bankruptcy scheme that Congress intended. Absent Congressional action, which is not on the horizon, it seems unlikely that courts would widely conclude that these provisions can be overridden by private parties through pre-petition contracts.

If that view is correct, then an arbitral award that produces a result contrary to the result that bankruptcy law would produce under the same circumstances is in violation of public policy. Combined with the principle that arbitration is a form of contract, this conclusion provides a basis for bankruptcy courts to monitor arbitral awards to ensure they do not compromise the rights of creditors. In the next section, I explain how this could work.

\section{Public Policy as Grounds for Review of Arbitral Awards in Bankruptcy}

Under the FAA, if the parties in their arbitration agreement agree that the arbitral award shall be entered as a judgment of a court, then the specified court or a United States district court must enter the award as a judgment unless it decides to vacate, modify, or correct the award under one of the provisions of the FAA. ${ }^{166}$ In bankruptcy, the Bankruptcy Court stands in the shoes of the District Court. It can issue orders and judgments for core claims and can submit proposed findings of fact and conclusions of law for noncore claims. When a Bankruptcy Court compels arbitration of a claim disputed in the bankruptcy proceeding, it becomes the court to which the parties apply for enforcement in the first instance.

Ignoring for now whether the matter is core or noncore, assume that a Bankruptcy Court orders the parties to arbitrate a matter disputed in the bankruptcy

provisions of the Bankruptcy Code which limit the effectiveness of certain contractual provisions that take effect upon the filing of a bankruptcy case, see $\$ \S 363,365,541$; and (3) the Bankruptcy Code extinguishes the private right of freedom to contract around its essential provisions."); see also Farm Credit of Cent. Fla. v. Polk, 160 B.R. 870, 873-74 (M.D. Fla. 1993) (pointing out policy reasons behind automatic stay of promoting orderly administration of estate by allowing debtor to gather assets and distribute them equally should keep pre-petition agreements from being per se binding); In re Sky Group Int'l, Inc., 108 B.R. 86, 88 (Bankr. W.D. Pa. 1989) (stating stay goes into effect automatically "without regard to any further conduct by debtor or creditors . . . and can be compromised only when there is good reason to do so.").

165 Warren \& Westbrook, supra note 157, at 1199 ("Bankruptcy law, as currently formulated, is a mandatory system. A debtor in trouble may file for bankruptcy following a predetermined set of federal rules; most courts will not enforce prebankruptcy contractual agreements not to file, nor will they permit the parties to vary the applicable rules."). Professors Warren and Westbrook go on to demonstrate empirically that contractual bankruptcy systems would not produce the efficiency gains that their advocates claim, thus undercutting the normative argument for treating bankruptcy law as a system of default rules. See id. at 1253.

${ }^{166} 9$ U.S.C. $\S 9(2000)$. 
proceeding. The arbitration proceeds and an award is rendered. The Bankruptcy Court at that point stands in the shoes of the district court for purposes of enforcement of the award. Just as a district court normally must enter an award as a judgment in a non-bankruptcy case, the Bankruptcy Court should normally enter the award as a judgment or refer it to the district court for entry as a judgment. But it also has the power to review the award to determine, among other things, whether the award is in violation of public policy.

The Bankruptcy Court should, at that point, review the award to determine whether the award, if it had been made a term of the agreement ex ante, would be enforceable. In other words, the question is this: If the parties, pre-bankruptcy, had agreed to a contract term obligating them to do exactly what the award requires, would that contract term be enforceable? If it would, then the FAA requires enforcement. If it would not, then the Bankruptcy Court should vacate or remand the award as violative of public policy.

As an example of how this approach could work in practice, consider the facts of Ins. Co. of N. Am. v. NGC Settlement Trust \& Asbestos Claims Mgmt Corp. (In re National Gypsum Co. $)^{167}$ another of the leading cases on the enforceability of arbitration clauses in bankruptcy. In National Gypsum, the successor to a chapter 11 debtor contended that an insurance company's post-bankruptcy collection efforts violated the discharge injunction. The insurance company moved to compel arbitration under a pre-bankruptcy agreement that included an arbitration clause and that had been assumed by the debtor as part of the reorganization plan. ${ }^{168}$ The Bankruptcy Court found that it had core jurisdiction, giving it the discretion to refuse to compel arbitration, and that it was the more efficient forum for resolving the dispute. The Fifth Circuit upheld the Bankruptcy Court's refusal to compel arbitration, finding that the Bankruptcy Court had discretion to deny enforcement of arbitration of core claims and that, under McMahon, enforcement would "irreconcilably conflict with the Bankruptcy Code."169

The courts in National Gypsum short-circuited the arbitration process. They refused to allow the arbitration to go forward out of concern that a prospective award might compromise the discharge injunction. They never contemplated the possibility of going forward with the arbitration and then looking at the actual award to determine whether it in fact compromised the discharge injunction. But that case is one in which public policy review would have been particularly apt. Whether or not the Bankruptcy Code as a whole constitutes a system of mandatory rules, the provisions on discharge are unequivocally mandatory; they expressly limit and condition the circumstances under which a debtor may contract to waive discharge. ${ }^{170}$ A Bankruptcy Court reviewing an award in that case would have to determine whether the award effected a waiver of the discharge injunction, and if

\footnotetext{
${ }^{167}$ (National Gypsum), 118 F.3d 1056 (5th Cir. 1997).

${ }^{168} \mathrm{Id}$. at 1059.

${ }^{169}$ Id. at 1071.

${ }^{170} 11$ U.S.C. $\$ 524(\mathrm{c})(2006)$.
} 
so, whether the waiver would have been valid under section 524(c) if entered into prior to the discharge. If the court concluded that the award did not amount to a waiver of the discharge injunction, or that it satisfied section 524(c), it should enforce the award. This process - of allowing arbitration to proceed and then reviewing the award on public policy grounds-would give effect to the FAA, respect the parties' contractual commitments, and still allow a Bankruptcy Court to protect the integrity of the bankruptcy system.

Now consider another major case, U.S. Lines, Inc. v. Am. S.S. Owners Mut. Prot. \& Indem. Ass'n (In re United States Lines, Inc.), ${ }^{171}$ in which the debtors and their successor-in-interest trust sought a determination in the Bankruptcy Court of their rights in various indemnity insurance contracts. The insurance policies constituted the primary assets of the estate, and were to be used to pay personal injury claimants against the debtors. The policies included pay-first provisions requiring the debtors to pay claimants before seeking indemnification. Questions arose about the options for satisfying the pay-first obligations and about the amounts payable under the contracts. The insurers sought to compel arbitration under arbitration clauses in the contracts. The Second Circuit held that, because the insurance contracts were so critical to the administration of the estate, the dispute was a core proceeding. Apparently fearing that arbitration might produce a result leaving the estate barren, the court refused to enforce the arbitration agreement. ${ }^{172}$

In re United States Lines represents exactly the judicial approach to arbitration that the Supreme Court has repeatedly repudiated for the last three decades. The Court has made it abundantly clear that fears about arbitral competence are not grounds for refusing to enforce otherwise valid arbitration agreements. Parties are presumed to enter into arbitration agreements knowingly and willingly, and the Court believes they should be held to the terms of their arbitration bargains. Responding to the argument that federal statutory claims are not arbitrable in Mitsubishi Motors Corp. v. Soler Chrysler-Plymouth, Inc., ${ }^{173}$ the Court said, "By agreeing to arbitrate a statutory claim, a party does not forego the substantive rights afforded by the statute; it only submits to their resolution in an arbitral, rather than a judicial, forum .... Having made the bargain to arbitrate, the party should be held to it unless Congress itself has evinced an intention to preclude a waiver of judicial remedies for the statutory rights at issue." The Court has repeated that language in many cases, rejecting the "suspicion of arbitration" and finding that judicial reluctance to enforce arbitration agreements is "far out of step with our current strong endorsement of the federal statutes favoring this method of resolving disputes." 174

171197 F.3d 631 (2d Cir. 1999) (agreeing with bankruptcy court in finding declaratory proceedings brought by trustee were core).

${ }^{172} I d$. at $638-39$ (allowing bankruptcy court to enjoin arbitration of proceedings).

${ }^{173} 473$ U.S. 614 (1985).

${ }^{174}$ Gilmer v. Interstate/Johnson Lane Corp., 500 U.S. 20, 30 (1991) (enforcing arbitration agreement over argument of ADEA violation (quoting Rodriguez de Quijas v. Shearson/Am. Exp., Inc., 490 U.S. 477, 481 (1989))). 
The claims at issue in In re United States Lines involved routine contract construction. They are the kinds of claims that the Supreme Court has said over and over are conducive to arbitral resolution. The fact that the resolution of those claims could have a substantial impact on the parties, creditors, or even the legal system is simply not a reason not to enforce a valid arbitration agreement. The Bankruptcy Court in that case should have first determined whether the arbitration process would unduly hamper the trust's ability to vindicate its and its creditors' rights. If it found that arbitration could proceed without undue expenditure of time and resources, it should have compelled arbitration. It would then have had the opportunity to review the award to determine whether the award, if entered into as a contract term, would have violated a provision of the Bankruptcy Code.

Because the parties could have spelled out the precise terms under which the contracts provided for indemnification, it seems extremely unlikely that an award would violate public policy in that way. The parties contracted to have an arbitrator determine the terms of the indemnification in the event of a disagreement, and that is what they should get. There is no justification for a bankruptcy judge to usurp that function.

\section{Protocols FOR ARBITRATION OF DISPUTES IN BANKRUPTCY}

My contention is that bankruptcy courts should normally enforce arbitration agreements - of both core and noncore claims - unless the costs of arbitration would preclude the parties from effectively vindicating their statutory bankruptcy rights. I then suggest that bankruptcy courts can guard against unfairness caused by arbitration through public policy review of awards. For this approach to work, bankruptcy courts need to have confidence that arbitration will proceed efficiently and that they will have sufficient information in the award to evaluate it according to the public policy criteria. The major arbitration providers, primarily the American Arbitration Association ("AAA"), can provide that assurance through protocols for the arbitration of disputes in bankruptcy.

AAA has protocols in place for the handling of arbitration in several controversial areas, including the arbitration of consumer disputes and the arbitration of employment disputes. ${ }^{175}$ The protocols are designed to ensure that the arbitration process is fair and effective for the type of dispute in question. For example, the Consumer Due Process Protocol call for arbitration of consumer disputes to be conducted at a place that is reasonably convenient for both parties, to entail a reasonable cost given the type of dispute, and to allow for either party to request an explanation of the award. ${ }^{176}$ AAA rules applicable in consumer disputes

175 AAA has recently announced that it will no longer arbitrate the highly controversial consumer creditcard disputes. It has made no announcements regarding arbitration of other types of consumer disputes. See Robin Sidel \& Amol Sharma, Credit Card Disputes Tossed Into Disarray, WALL ST. J., July 21, 2009, at Al.

176 See American Arbitration Association, Consumer Due Process Protocol, http://www.adr.org/sp.asp?id=22019 (last visited Oct. 14, 2009). 
ensure that the protocols are followed, by, for example, providing for expedited procedures and limiting the fees that the consumer must pay. ${ }^{177}$ The Employment Due Process Protocol and the associated Employment Arbitration Rules and Mediation Procedures adopt protections designed to ensure that employees are not disadvantaged by pursuing arbitration instead of litigation, for example by providing that when an employer compels arbitration through an employerpromulgated plan, the employer must pay the arbitrator's fees unless the employee, post-dispute, voluntarily agrees to contribute. ${ }^{178}$

AAA and other providers should promulgate protocols and rules designed to ensure that arbitration of disputes arising in the context of bankruptcy does not unduly impinge upon the bankruptcy process. I will not attempt here to propose specific protocols and rules. I will only suggest that the arbitration should be as efficient as possible so as not to delay resolution of the bankruptcy, and that the greater share of the cost should fall on a creditor seeking to enforce an arbitration agreement against a Trustee or DIP. In addition, provision should be made for a written award to give the bankruptcy court the means to assess the award for purposes of public policy review. Arbitrators probably should have a background in bankruptcy to minimize the likelihood of an award contravening the policies embodied in the Bankruptcy Code.

If those sorts of protections are in place, bankruptcy judges should be willing to compel arbitration. Of course, the choice of whether to seek arbitration will ultimately lie with the parties. Parties may choose not to seek arbitration of an otherwise arbitrable dispute if they think a bankruptcy court will simply undo the award at the enforcement stage. The reason that judicial review of arbitral awards is normally so truncated is that parties will be less likely to use arbitration if they believe courts will not enforce awards. Robust judicial review could make arbitration simply one more step in an increasingly long and expensive litigation process. If bankruptcy courts routinely vacate awards on public policy grounds, arbitration will lose much of its value in the bankruptcy setting.

That is a real risk, but I believe it represents a fair trade given the important public policy interests at stake in bankruptcy. Parties to an arbitration agreement can choose to enforce the agreement knowing that a bankruptcy judge will review any award, or they can forego arbitration and submit the dispute to the bankruptcy judge in the first instance. In this way, parties will be discouraged from using arbitration as a "hammer" to extract concessions as part of the bankruptcy.

\footnotetext{
177 See American Arbitration Association, Consumer-Related Disputes Supplementary Procedures, http://www.adr.org/sp.asp?id=22014 (last visited Oct. 14, 2009).

178 See American Arbitration Association, Employment Arbitration Rules and Mediation Procedures, http:/www.adr.org/sp.asp?id=32904 (last visited Oct. 14, 2009).
} 


\section{CONCLUSION}

Arbitration and bankruptcy both occupy special places in the American system of dispute resolution. They are the creatures of federal statutory schemes that allow them to displace traditional adjudication for a wide variety of disputes. When parties resort to either arbitration or bankruptcy, they forego many of the due process protections to which they would otherwise be entitled, and gain instead a process that values efficiency over either procedural nicety or legal certainty.

When arbitration and bankruptcy meet, it can be tempting to see an inherent tension, a clash between two competing modes of dispute resolution. Most courts addressing the intersection of arbitration and bankruptcy have seen things in that way. They treat arbitration as a quasi-judicial dispute resolution forum in competition with bankruptcy, and decide whether to enforce arbitration agreements by assessing the competing policy interests at stake. Implicitly, they assume that either the policy supporting arbitration or the policy supporting bankruptcy will have to give way to the other.

I have attempted to show that another way of understanding the relationship between arbitration and bankruptcy exists. In my view, arbitration and bankruptcy can work in tandem, with respect paid to the policies of each. The key to this approach is to understand arbitration not as a competing quasi-judicial forum, but as a species of contract. Parties enter into arbitration agreements because they recognize that they cannot foresee all possible eventualities and disputes that might arise, and that it would not be efficient to provide for all eventualities even if they could be anticipated. Arbitration provides a mechanism to resolve contractual disagreements as they happen, using a neutral person as a designated "contract reader." The arbitrator supplies the "terms" that the parties would have agreed upon if they had foreseen the dispute and planned for it in the contract. The award is the equivalent of a contract term.

Bankruptcy courts do not have the power to re-write contract terms. Whether the term is one written into the agreement originally or one supplied later by an arbitrator, the result should be the same. The bankruptcy court should honor the terms of the agreement. If the terms create an obligation arising in favor of the debtor, that obligation should be enforced by the estate. If the terms create an obligation on the part of the debtor, that obligation should be paid by the estate according to the statutory scheme.

This is not to say that arbitration and bankruptcy will never clash. Where arbitration would compromise important interests at stake in the bankruptcy, arbitration should give way. That can happen either because the arbitration process imposes unacceptable costs, in either money or time, or because the arbitration award is skewed so as to create unfairness to the debtor or other creditors. But those problems can be addressed in ways that respect arbitration. Bankruptcy courts can decline to enforce arbitration agreements where the cost of the process would compromise the ability of the debtor or creditors to vindicate their statutory 
[Vol. 17: 503

bankruptcy rights. And on the back end, bankruptcy courts can vacate or remand awards where the award, if made as a contract term, would contravene the express policies of the Bankruptcy Code. 